\title{
Three decades of research on the greater Agulhas Current
}

\author{
J. R. E. Lutjeharms \\ Department of Oceanography, University of Cape Town, 7700 Rondebosch, South Africa
}

Received: 8 June 2006 - Published in Ocean Sci. Discuss.: 25 July 2006

Revised: 22 January 2007 - Accepted: 22 January 2007 - Published: 23 February 2007

\begin{abstract}
The greater Agulhas Current has been shown to be a key link in the global thermohaline circulation and an increased understanding of this current system is therefore of more than just local interest. Knowledge on the Agulhas Current system has in fact increased enormously over the past 30 years. This review covers some aspects of what has been learnt on the northern and the southern parts of the Agulhas Current proper and their influence on the waters and circulation of the adjoining continental shelf. It also discusses the Natal Pulse and new information that has been gained on how it is triggered and what influence it has. It deals with the Agulhas retroflection, the shedding of Agulhas rings and the movement and characteristics of these rings that contributes to the meridional overturning circulation of the global ocean. The Agulhas Return Current forms part of the final outflow of the system and current knowledge on that current is appraised. The sources of the Agulhas Current have been a controversial subject for many years and this dispute continues. This is described and discussed, based on what information has been gained from research over the past three decades. Building on what is currently known, some suggestions are given on the most important remaining knowledge gaps and how these could most efficaciously be filled.
\end{abstract}

\section{Introduction}

It is of some historical interest that the Agulhas Current was one of the first western boundary currents described scientifically in some detail (Rennell, 1832). The reason for this is not difficult to understand. This strong, southward-setting current constituted a major obstruction to commercial vessels sailing from Europe to the Indies at the time. Having a strong maritime interest, the Dutch in particular gave the current a

Correspondence to: J. R. E. Lutjeharms

(johann.lutjeharms@uct.ac.za) lot of research attention (e.g. Van Gogh, 1857) even to the extent of investigating its influence on the overlying atmosphere and thus on local storms (Van Gogh, 1878), generally considered a very modern research topic. This early research, largely based on ships' drift and measurements of sea surface temperatures, lead to an excellent, prescient portrayal of an Agulhas retroflection (see Lutjeharms et al., 1992). Regrettably, most of this fundamental knowledge was subsequently lost.

The next spurt in research on the Agulhas Current and the circulation of the South-West Indian Ocean as a whole occurred in the 1930s, carried out almost entirely by British and German scientists (see e.g. Lutjeharms and Kortum, 2003). The big steps forward in understanding brought about particularly by German research was subsequently also lost to science (Lutjeharms and Kortum, 2006) and when the International Indian Ocean Expedition of the 1960 came about (Wüst, 1960) it started as if on a blank sheet. One of the first and most important directed investigations on the Agulhas Current as a whole was conducted only in 1969 as the "Combined Agulhas Cruise" (Bang, 1970a). This led to a whole number of new concepts on the Agulhas Current (e.g. Bang, 1970b), the rediscovery of the retroflection (and the creation of the term; viz. Lutjeharms, 1980; Lutjeharms et al., 1992) and some thoughts on the possibility of ring shedding at the termination of the current. This benchmark in knowledge in the 1970s is conceptually portrayed in Fig. 1.

A number of key elements of the Agulhas Current system are immediately apparent in Fig. 1. First, the Agulhas Current is seen to be fed largely by water coming from its presumed precursor in the Mozambique Channel, the Mozambique Current. This water is joined by that of another broad tributary from east of Madagascar, the East Madagascar Current, to form the Agulhas Current that was believed to be thus fully constituted at about $30^{\circ} \mathrm{S}$ where some water from a "Return Agulhas Current" contributed the last elements to the flow. The Agulhas Current water is then portrayed as

Published by Copernicus GmbH on behalf of the European Geosciences Union. 


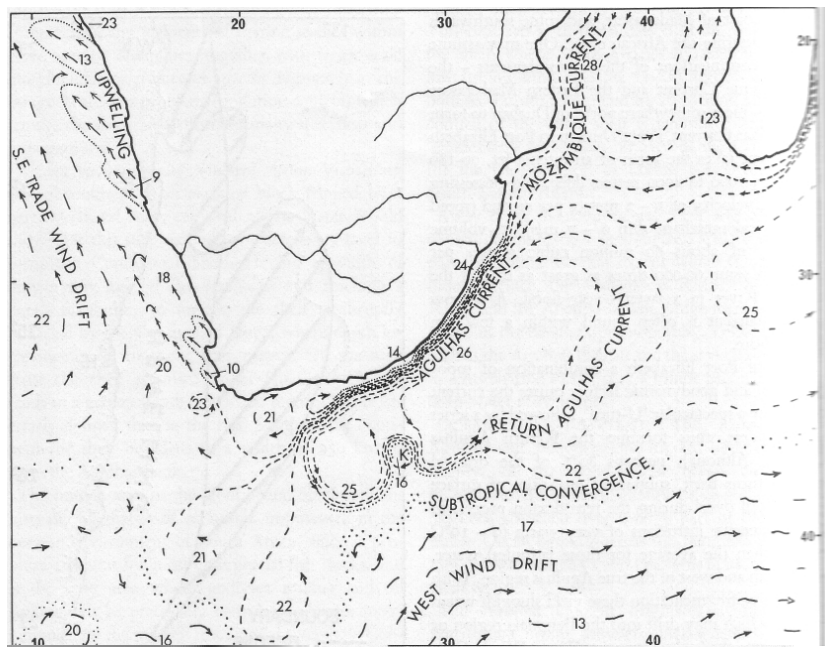

Fig. 1. The general circulation of the South West Indian Ocean as it was understood in the 1960s (Bang, 1973b). Particularly noteworthy is the detail given for the assumed circulation south of Africa and along its west coast. The contrast between these regions and others in the portrayal is directly due to the fact that recent research cruises had investigated these former regions, but not elsewhere.

flowing poleward along the shelf edge of southern Africa, turning back on itself south of Africa and thus returning most of its water eastward. Not much succeeds in proceeding further than about $35^{\circ} \mathrm{E}$, most returning in the aforementioned "Return Agulhas Current". At the retroflection of the current there is evidence for some large vortices. The Subtropical Convergence is depicted as forming the southern boundary to the Agulhas Current system. Along the west coast of southern Africa a few coastal upwelling cells are evident. Their convoluted fronts are shown in some detail. This specific detail is the direct result of a particular and long lasting interest in these features by Bang (1973).

It is immediately clear that some components of the circulation in the South-West Indian Ocean are also shown in considerable detail in Fig. 1, whereas other parts are portrayed in only the vaguest ways. This was a direct consequence of the data available to Bang at the time. Much work had been done in the Benguela upwelling area by the then Sea Fisheries Branch and the detailed cruise on the Agulhas Current mentioned above had just taken place (Bang, 1970a). Both these systems are therefore portrayed with some confidence. By contrast, hardly any appropriate data were available for the Mozambique Channel and nothing at all for the region east of Madagascar. The flow in these regions is therefore given in only the broadest terms. This all changed with the International Indian Ocean Expedition (e.g. Wyrtki, 1971) and the subsequent rapid growth in interest in the region, both nationally in South Africa as well as internationally. One of the main components that received a lot of attention in the 1960s and 1970s was the northern Agulhas Current.

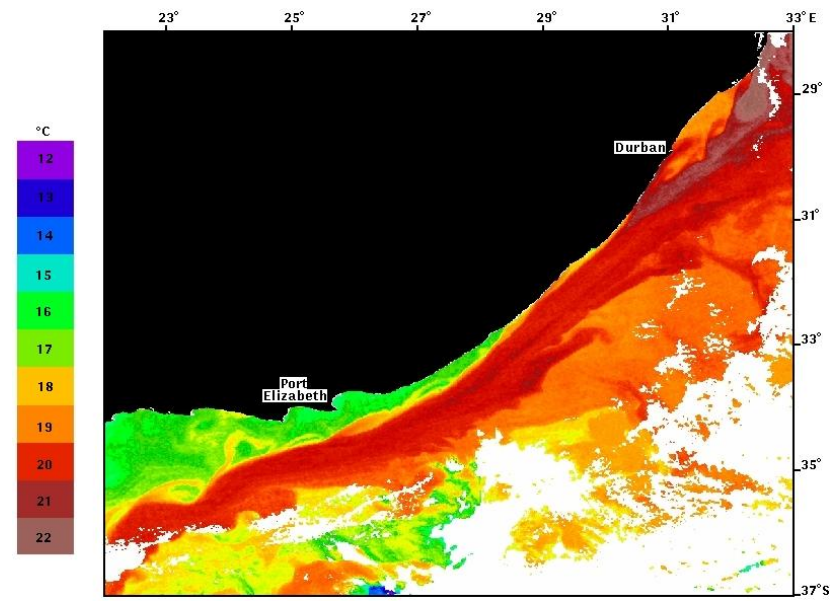

Fig. 2. The surface expression of the northern Agulhas Current from satellite thermal infrared (Lutjeharms, 2006b). The narrow, nearly linear trajectory of the current is clear. Near $30^{\circ} \mathrm{S}$, directly upstream of Durban, there is some evidence of shear edge disturbances on the inshore edge of the current. Downstream of Port Elizabeth there are indications of the onset of meanders. This image is from the NOAA 9 satellite for 26 August 1985.

\section{Agulhas Current}

With the advent of satellite remote sensing it was soon discovered (Harris et al., 1978; Lutjeharms, 1981) that the Agulhas Current can be considered to consist of a northern $\mathrm{Ag}$ ulhas Current and a southern Agulhas Current. These two parts have distinctly different trajectorial behaviours.

\subsection{Northern Agulhas Current}

The northern Agulhas Current has been shown to be quite remarkable as a western boundary current for its invariant path. This is evident in Fig. 2. The current core can be seen to follow the shelf edge very closely. This can also be seen very clearly in Fig. 3. By comparison other western boundary currents such as the Gulf Stream and the Kuroshio exhibit substantial sideways meanders. The path given in Fig. 3 is based on a large number of vertical hydrographic sections across the current. The intersection of the $10^{\circ} \mathrm{C}$ isotherm with the $200 \mathrm{~m}$ isobath was taken as representative of the location of the core of the current (Gründlingh, 1983). On about 20\% of the sections there was no evidence of the Agulhas Current whatsoever, even up to a distance of $200 \mathrm{~km}$ offshore, suggesting the presence of an unusual, intermittent meander. About this more later.

The stability of the northern Agulhas Current has subsequently been studied and explained as being a consequence of a very steep continental slope (De Ruijter et al., 1999). The only place along its path where this does not hold is at the Natal Bight, a wider part of the shelf in a coastal offset north of Durban (see Fig. 3). The different behaviour of 
the current here is evident in Fig. 2 which shows that shear edge features are being formed here whereas they are absent along the rest of the current. This may also be due to the wider shelf, allowing shear edge eddies to develop larger lateral expressions here.

The kinematic nature of this part of the current was studied in detail from Durban in the 1970s (e.g. Pearce, 1977) when the South African CSIR maintained an active research institute there, with a small research vessel, the "Meiring Naudé" (Gründlingh, 1988). It was shown that the Agulhas Current consisted of three primary zones, a sharp, inshore, thermal frontal zone, the core of the current and a more disperse offshore front. The temperatures were greater than $22^{\circ} \mathrm{C}$, the speeds $1.3 \pm 0.3 \mathrm{~m} / \mathrm{s}$ and the volume flux was estimated at $72 \mathrm{~Sv}\left(\mathrm{~Sv}=10^{6} \mathrm{~m}^{3} / \mathrm{s}\right)$ over the full depth of the current (Gründlingh, 1980). These investigations established the core parameters for the current in a relatively reliable fashion for the first time. These pioneering South African efforts were terminated in the 1980s (Lutjeharms and Thomson, 1993), but fortunately followed in the 1990s by the placement of current meter moorings in the current by British oceanographers (Beal and Bryden, 1999). The measurements from this project gave a very accurate, average value of the volume transport of $69.7 \pm 4.3 \mathrm{~Sv}$, the best to date.

Even more important, their precise measurements allowed the discovery of an Agulhas Undercurrent (Beal and Bryden, 1997) that had only been hypothesised before. This undercurrent was shown to have a volume flux of $4.2 \mathrm{~Sv}$ equatorward and to consist largely of modified Red Sea Water. The depth of the current was unexpectedly variable. By comparing three velocity sections at the same latitude, Donohue et al. (2000) were able to show that on occasion the current extends to the bottom whereas on other occasions its vertical penetration was only to a depth of $2300 \mathrm{~m}$. The temporal variability in these depth changes and the driving processes involved are not as yet known. However, the surface characteristics of the northern Agulhas Current were firmly established by the 1980 s and the subsurface variables by the 2000s.

Of more local interest was the influence of the Agulhas Current on the circulation on the adjacent continental shelf and in particular on effluent dispersal (e.g. Gründlingh, 1974). A pioneering study of bottom sediments on this shelf and tell-tale morphological structures (Flemming, 1980) showed that the movement on the narrow shelf was parallel to the current - not unexpectedly - except in regions where the shelf is wide. Here the sediment movement is indeterminate. In general, the circulation on the aforementioned Natal Bight has been thought of as consisting of cyclonic eddies (e.g. Schumann, 1982; Malan and Schumann, 1979). Not so intuitively expected was the finding that the current north of the Natal Bight is dominated by movement over the continental shelffto the north east (Flemming and Hay, 1988). This meant that the location along this coast where the Agulhas Current can be thought of as starting was not known

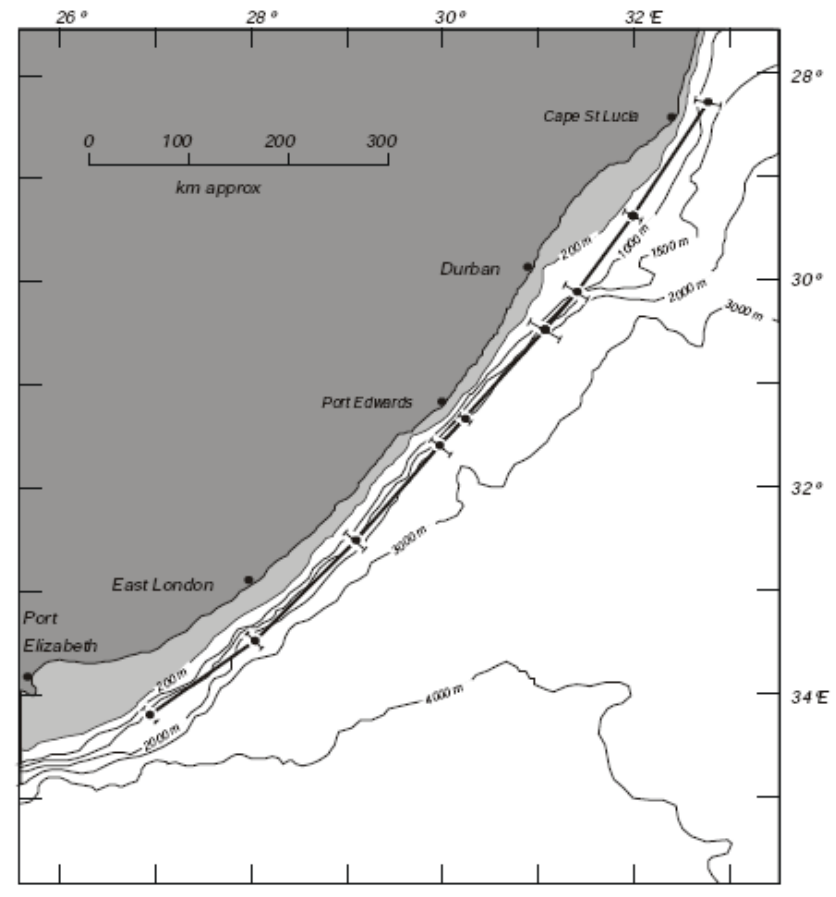

Fig. 3. Location of the core of the northern Agulhas Current (after Gründlingh, 1983). Error bars show the standard deviation at each section, superimposed on the bathymetry. The wider part of the continental shelf between Durban and Cape St. Lucia constitutes the Natal Bight.

and this ignorance has remained. The northern Agulhas Current has been shown to have some other unusual influences on the shelf, by forcing a distinctive upwelling cell near Cape St. Lucia.

This cape lies at the northern edge of the Natal Bight (Fig. 4). Unusual concentrations of low temperature, high chlorophyll and high nutrients were observed here (e.g. Carter and Schleyer, 1988; Carter and d'Aubrey, 1988) as part of investigations to establish baseline values before a large industrial outfall was constructed in the 1970s. These anomalous values for hydrographic variables were explained (Lutjeharms et al., 1989a) when the availability of satellite remote sensing made it evident that an upwelling cell was located off St. Lucia more or less permanently. A subsequent research cruise that covered the whole Natal Bight for the first time in 1989 (Lutjeharms et al., 2000a; Meyer et al., 2002) showed unambiguously that this active upwelling cell is a "point" source of nutrients for the shelf of the Natal Bight as a whole and has the highest primary productivity for the whole region (Fig. 4). Analyses of the winds in the region have exhibited no statistical correlation between this upwelling and wind direction, indicating that this coastal upwelling is not wind induced. Theoretical studies (Gill and Schumann, 1979) have indicated that when an intense, jetlike current - such as the Agulhas Current - moves from a narrow shelf to a wider shelf, upwelling inshore of the 


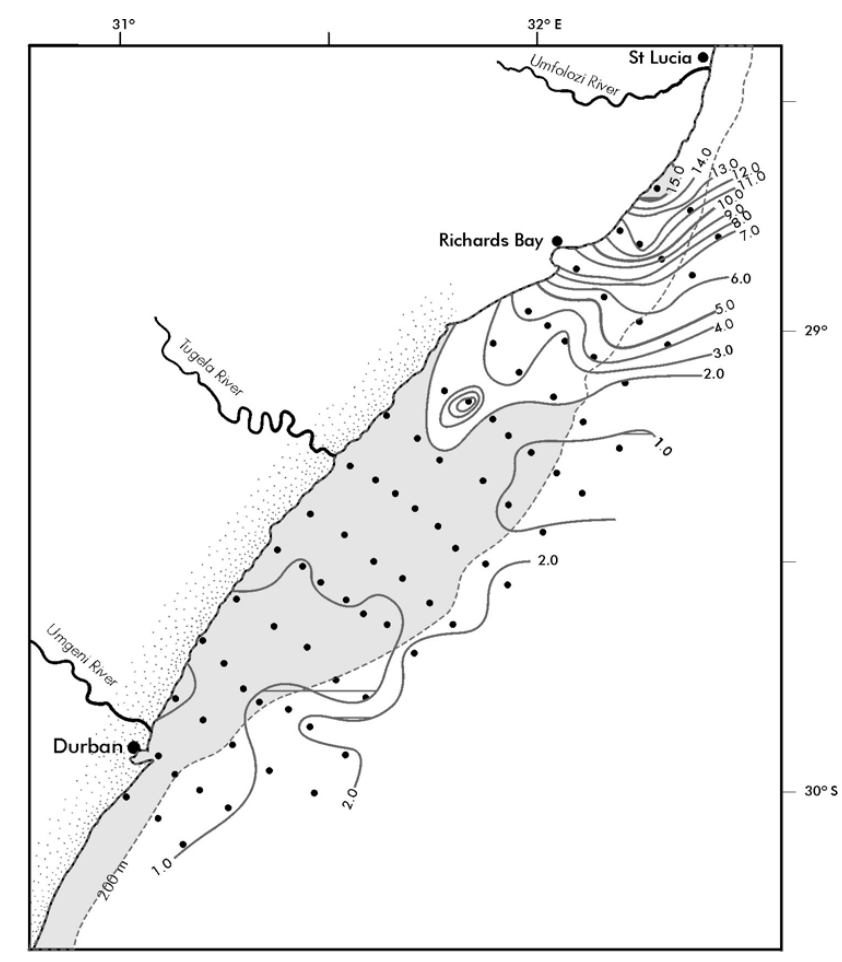

Fig. 4. The distribution of phosphate over the Natal Bight (after Meyer et al., 2002). That area shallower than $200 \mathrm{~m}$ and not covered by phosphate values above $2 \mu \mathrm{mol} / \mathrm{l}$ is shaded to highlight the unusual width of the shelf here. The presence of a distinct and active upwelling cell near St. Lucia is evident. The influence of this nutrient-rich water did not extend farther than half the length of the bight on this occasion. Dots denote the location of hydrographic stations for a quasi-synoptic cruise carried out in 1989.

current will be induced. The upwelling at St. Lucia is therefore most probably dynamically driven by the adjacent current as a result of the appropriate shelf morphology. Local observations, particularly those taken in the 1970s, have also established other regional circulation phenomena, such as a persistent eddy off Durban.

As can be seen in Fig. 3, the shallow region of the Natal Bight ends abruptly at Durban. The Agulhas Current follows the shelf edge of the Natal Bight closely (Pearce et al., 1978), but overshoots at the shelf offset at Durban. A tight lee eddy has often been observed here (Anderson et al., 1988) and is believed to be driven by the passing current. It is clearly evident in most, more modern, hydrographic observations in the region as well (e.g. Meyer et al., 2002). The discovery of this feature makes an understanding of the movement of some oil spills here much easier (Gründlingh and Pearce, 1990). Mesoscale circulatory features such as these are much more prevalent on the landward side of the southern Agulhas Current.

\subsection{Southern Agulhas Current}

Downstream of Port Elizabeth the continental shelf widens considerably to form the broad expanse of the Agulhas Bank south of Africa (viz. Fig. 18). Along the eastern edge of this bank the Agulhas Current starts to develop meanders (Harris et al., 1978) very similar to those found on the comparable Gulf Stream. These meanders have been shown to grow downstream (Lutjeharms et al., 1989b) and have attendant cyclonic eddies and warm water plumes. The latter may extend over large parts of the bank even influencing the waters and the biota in bays on the coastline (e.g. Goshen and Schumann, 1988, 1994). The distribution of shear edge eddies seems to be concentrated in the eastward facing bight of the Agulhas Bank and this geographical predominance has subsequently been fairly well simulated by numerical models (Lutjeharms et al., 2003a). A substantial body of knowledge has therefore been built up concerning the shear edge features of the southern Agulhas Current. Their influence on Agulhas Bank waters has however as yet not been quantified. Plumes from the Agulhas Current have also been implicated in inter-ocean exchange.

Once past the most southern tip of the Agulhas Bank the southern Agulhas Current proceeds into the South Atlantic as a free inertial jet, but still generates plumes of warm water at its northern border (Lutjeharms et al., 1996). These Agulhas filaments have been observed to be only about $50 \mathrm{~m}$ deep, but carry anomalous warm, salty water into the Atlantic Ocean. Because of their limited vertical extent the heat in these filaments is soon lost to the atmosphere, this being a region of large ocean to atmosphere heat flux (e.g. Walker and Mey, 1988; Rouault and Lutjeharms, 2000). The inter-ocean heat flux by Agulhas filaments has therefore been considered to be minimal. The inter-ocean salt flux is by contrast not lost, but constitutes only about $10 \%$ of the salt flux achieved by other processes.

Agulhas filaments have been shown to follow the western shelf edge of the Agulhas Bank quite closely, but their trajectories are often disturbed by a cyclonic eddy prevalent on the western side of the bank (Penven et al., 2001). Modelling has suggested that this lee eddy is driven by the passing Agulhas Current, fed cyclonic vorticity from passing shear edge eddies and that it eventually escapes into the South Atlantic (Lutjeharms et al., 2003b) to join a plethora of eddies and rings in the Cape Basin west of Cape Town. The location and persistence of this lee eddy may interfere with the shelf edge jet (Boyd et al., 1992) supposedly present here most of the time.

The warm waters of the Agulhas Current have for a long time been considered to play an important role in the weather and the climate of the southern African subcontinent. This was quantified for the first time by Walker (1990) who has been able to show that the sea surface temperatures of the Agulhas Current are directly linked to summer rainfall over South Africa. Work of this nature has continued (e.g. Crimp 
et al., 1998; Reason, 2001) and is being extended and refined. Other studies have tried to investigate the influence of sea-air interaction on extreme weather systems (e.g. Walker and Lindesay, 1989). Studies dedicated to the influence of the southern Agulhas Current have shown (Rouault et al., 2002) that air travelling over the current for a long time and gaining both heat and moisture may considerably enhance the intensity of inland storms. This type of sea-air exchange had long been expected since the formation of lines of cumulus clouds over the current had frequently been seen in satellite images (Lutjeharms et al., 1986a). To observe the influence of the Agulhas Current on the overlying atmosphere more precisely, a focussed programme of investigations was started in the 1990s to measure the fluxes in situ (Rouault and Lutjeharms, 1994). These demonstrated that there was substantial moisture uptake by the atmosphere over the current (Lee-Thorp et al., 1999) with the marine boundary layer affected to a height that could indeed induce cumulus cloud formation (Lee-Thorp et al., 1998). In this way the influence of the Agulhas Current on the air passing over it has been fairly well quantified in the 1990s.

Apart from the meandering and the production of shelf edge features, the southern Agulhas Current has been shown to be very similar to the northern Agulhas Current. Its volume flux has first been estimated to be $125 \mathrm{~Sv}$ (Jacobs and Georgi, 1977) implying that the volume flux increases by about $6 \mathrm{~Sv}$ for every $100 \mathrm{~km}$ travelling downstream in the current. Its surface temperatures are $23-26^{\circ} \mathrm{C}$ and its surface salinity 35.4 (Gordon et al., 1987). Surface speeds may be in excess of $2 \mathrm{~m} / \mathrm{s}$. In one other aspect it is also similar to the northern Agulhas Current, namely coastal upwelling driven by the Agulhas Current.

It has been shown that at the most upstream point of the Agulhas Bank, near Port Elizabeth (viz. Fig. 3), there is persistent upwelling. Here, at Port Alfred, the southern Agulhas Current experiences roughly the same shelf configuration as does its northern counterpart at St. Lucia, namely a narrow shelf that increases in width downstream. The surface expression of the Port Alfred upwelling cell seems to be influenced by the wind (Rouault et al., 1995) whereas the subsurface inflow of cold water has been inferred as being perennial (Lutjeharms et al., 2000b). The surface expression as shown by temperatures at the sea surface is given in Fig. 5. From here water has been shown to move over the bottom of the rest of the Agulhas Bank (Lutjeharms and Meyer, 2006) in the form of a cold ridge that roughly follows the $100 \mathrm{~m}$ isobath (Swart and Largier, 1987). This cold water inflow has been surmised to be the mechanism for the cooling of water over the Agulhas Bank from below in summer (Lutjeharms, 1998) as it is heated by insolation from above. This inflow from an upwelling cell also leads to an anomalous insertion of nutrients (Lutjeharms et al., 1996) that is not normally expected on a shelf of this kind, making it potentially more biologically productive than elsewhere.

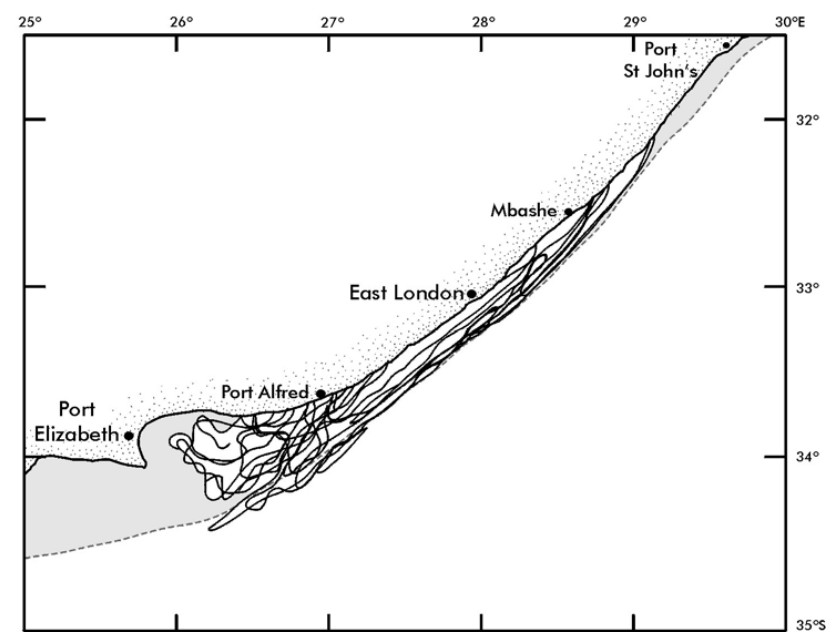

Fig. 5. Outlines of cold, upwelled water inshore of the Agulhas Current at Port Alfred (after Lutjeharms et al., 2000b). These outlines were for the months of January to May 1991 and show that the geographic extent of the upwelling may be quite variable, but that the centre seems to remain at Port Alfred.

Normal, wind-driven coastal upwelling has also been observed at headlands of the coastline (Schumann et al., 1982) particularly on the western side of the Agulhas Bank (Boyd et al., 1985) which can in some ways be considered part of the Benguela upwelling regime (Lutjeharms and Meeuwis, 1987). Since the winds here are predominantly in an easterly or westerly direction, wind-driven upwelling could be expected along this zonal coastline. The reaction of waters at the coast to strong winds from the east has been shown to be very rapid (e.g. Beckley, 1983; Lutjeharms, 1998) and can have an important influence on the ecology of the adjacent coastline (Schumann et al., 1988).

\subsection{Natal Pulse}

As mentioned above, there had been indications in the 1970s that the Agulhas Current experiences an intermittent meander of substantial dimensions. Gründlingh (1979) was able to capture a meander in the Agulhas Current with hydrographic observations. Satellite remote sensing subsequently made it possible to study the trajectory of the current in more detail and over a longer period (e.g. Lutjeharms and Roberts, 1988) and it was discovered that singular meanders on the current are an inherent part of its dynamics, that these meanders move downstream at a more-or-less constant speed and that they grow during this movement (Fig. 6). Since their origin is the Natal Bight, they have been dubbed the Natal Pulses. Some evidence has been reported that similar flow disturbances may be created at the Delagoa Bight in southern Mozambique (Gründlingh, 1992), but these have to date not been observed to move far pole-wards. So what is it that makes the Natal Bight so special that it is the exclusive gestation region for Natal Pulses? 


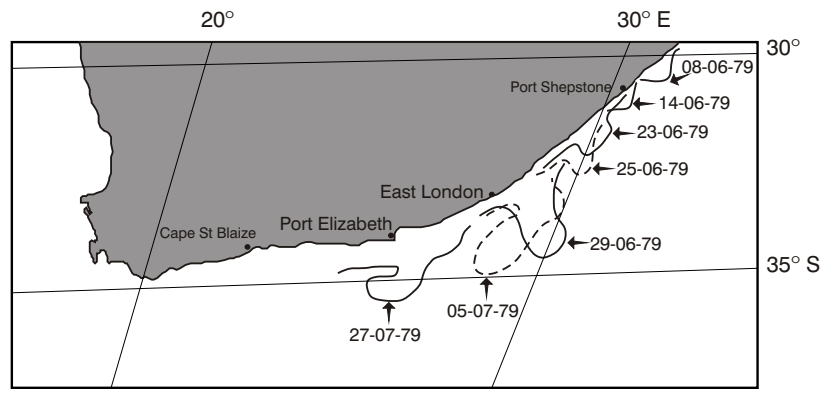

Fig. 6. Sequential outlines of the landward border of the Agulhas Current for the dates shown. This series shows the downstream progression and growth of a Natal Pulse. This information is from satellite infrared imagery (after Lutjeharms and Roberts, 1988).

As mentioned before (viz. Fig. 3), the slope of the shelf along which the northern Agulhas Current flows is quite steep, with the exception of that off the Natal Bight. De Ruijter et al. (1999a) have shown that the Agulhas Current has the potential to become unstable only where the continental slope is weak, therefore the Natal Bight would be an ideal location for this to happen. However, to cross the threshold to become unstable here the Current needs to become more intensified or to be perturbed from its normal condition. Such a perturbation could come about by the adsorption of an offshore eddy onto the current. Schouten et al. (2002a) have elegantly shown that such adsorptions do occur and indeed do have the triggering effect previously only surmised. It has also been shown that these Natal Pulses extend throughout the depth of the Agulhas Current (Lutjeharms et al., 2001) and that they cause current reversals on the adjoining shelf (Lutjeharms and Connell, 1989).

The downstream growth of the Natal Pulse (viz. Fig. 6) may have some dramatic consequences south of Port Elizabeth. About $200 \mathrm{~km}$ south of the shelf lies the Agulhas Plateau, a relatively shallow region. The Agulhas Current has to pass through this gap, as has the Agulhas Return Current on its way east. If the Agulhas Current is forced too far off course by a well-developed Natal Pulse, its path will intersect the Agulhas Plateau and it will turn back on itself, i.e. retroflect before it gets any farther, due to vorticity considerations. This upstream retroflection has in fact been observed (e.g. Lutjeharms and van Ballegooyen, 1988a) and has global implications to be discussed below. This has to do with the inter-ocean exchange of oceanic water masses at the Agulhas retroflection (De Ruijter et al., 1999b) that has been especially studied in the 1990s.

\section{Agulhas retroflection}

A temperature image of the retroflection of the current is given in Fig. 7. This shows clearly how the southern Agulhas Current overshoots the southern tip of the wide shelf

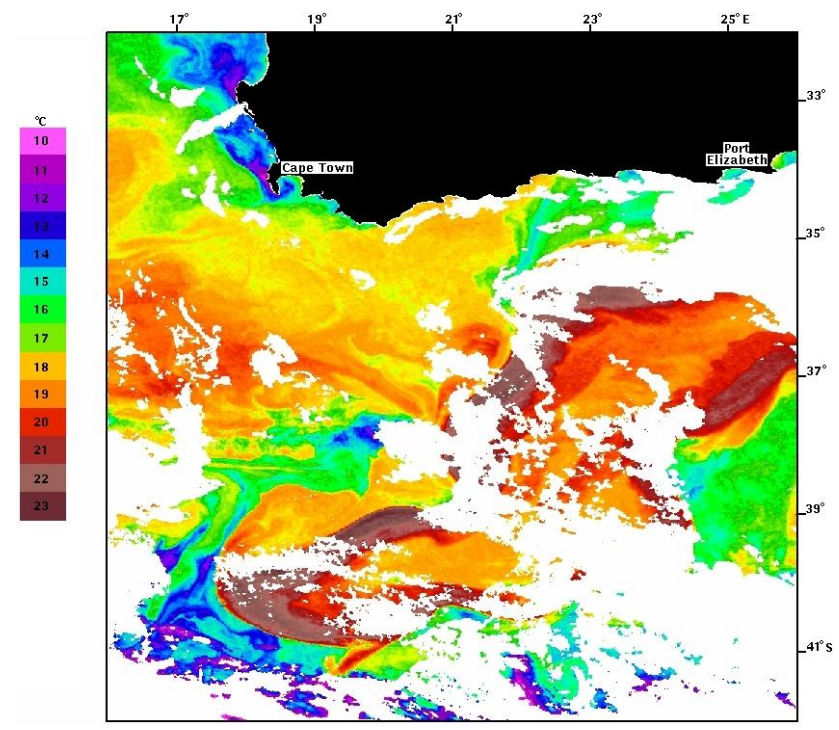

Fig. 7. Thermal infrared satellite image of the termination region of the Agulhas Current on 13 November 1985 obtained from instruments on board a NOAA satellite (Lutjeharms 2006b). The red band shows the location of the southern Agulhas Current, the Agulhas Return Current and the retroflection south of Africa that connects these two. Notice the cold water $\left(<15^{\circ} \mathrm{C}\right)$ to the south that constitutes the Subtropical Convergence and a wedge of such cold water moving northward on the westward side of the retroflection loop. The cold water on the west coast of southern Africa is the surface expression of wind-driven coastal upwelling.

south of Africa and then retroflects to become the eastward flowing Agulhas Return Current. The width of the current does not change much during this process, nor does its depth (Gordon et al., 1987). The depth of the current at this point has been observed to be about $4000 \mathrm{~m}$ (Schmitz, 1996) and the average diameter of the retroflection loop 300 to $400 \mathrm{~km}$ (Lutjeharms and van Ballegooyen, 1988b). Speeds in this part of the current can reach $2 \mathrm{~m} / \mathrm{s}$. This configuration of the current does not stay the same, but the retroflection loop continuously progrades into the South Atlantic. At the extreme of each progradation the retroflection loop is short circuited (Fig. 8) and a ring is occluded (Lutjeharms and Gordon, 1987). Could the arrival of a Natal Pulse in the retroflection region trigger such a ring shedding event?

Careful analysis of satellite information (Van Leeuwen et al., 2000) has shown that this is indeed the case, but that ring spawning can also occur spontaneously if a long period passes without a Natal Pulse. One might well ask what would be the effect of such a durable absence of Natal Pulses on the inter-ocean exchange south of Africa. Current thinking (e.g. Penven et al., 2006) is that the shedding of Agulhas rings would persist, but at a reduced frequency.

The first development of the concept of a true retroflection of the Agulhas Current was by Bang (1970b), but remained dormant till the late 1980s when satellite thermal imagery 
made the turning back on itself of the current more clearly visible than before and the notion was revived (Lutjeharms, 1981). Proof of the ring shedding process then also became possible for the first time (Lutjeharms and van Ballegooyen, 1988b).

Why should the Agulhas Current retroflect in such a dramatic way? A large number of investigations on the matter have been carried out (e.g. De Ruijter, 1982; De Ruijter and Boudra, 1985; Dijkstra and de Ruijter, 2001a, b). Much of this has been ably summarised by de Ruijter et al. (1999b). The answer is not yet unambiguously clear. A number of mechanisms have been considered such as inertia, the betaeffect and side-wall friction (De Ruijter, 1982). Perhaps all of these play a role - which may vary with time - but in as yet unknown proportions.

Why should such a lot of international attention have been given over the past two decades to a process far away from the main centres of oceanographic research, at the southern tip of Africa? The main reason is the inter-ocean exchange of water that takes place here (Gordon, 1985).

As will be seen in the discussion below, Agulhas rings carry vast amounts of warm, salty Indian Ocean water into the South Atlantic Ocean. It has been shown that this interocean leakage forms a crucial link in the climatically crucial global, thermohaline circulation (Gordon, 1986). Based on a palaeo-climatological investigation it has even recently been demonstrated (Peeters et al., 2004) that this inter-ocean leakage has been particularly strong at the end of each of the last five glacial periods, but that it has never been absent entirely (Rau et al., 2002). Modelling studies by Weijer et al. (1999, 2001, 2002) have in addition shown that a diminution in the exchange at the Agulhas retroflection leads inexorably to a slowing of the Atlantic Ocean's thermohaline overturning. The importance of this process of ring shedding at the Agulhas retroflection has thus been demonstrated during the past decade as have the mechanisms that control it. The latter may have to do with the triggering of Natal Pulses and these in turn may be influenced by eddy formation in the source regions of the Agulhas Current (Schouten et al., 2002b). About this more in Sect. 6.

The shedding of Agulhas rings has some secondary, attendant processes that may be locally important. First, the cyclonic lee eddy on the western side of the Agulhas Bank (Penven et al., 2001) has been observed sometimes to detach from the shelf edge and to move south-westward. In this process it may intersect the Agulhas Current retroflection loop (Lutjeharms et al., 2003b) and set off the formation of an Agulhas ring. The frequency with which these lee cyclones are shed and if they always trigger ring spawning events remains unknown. A second effect is evident in Fig. 7, namely the equatorward penetration of a wedge of cold water between a newly shed Agulhas ring and its parent retroflection. This cold water has been shown to extend to substantial depths (Lutjeharms and Fillis, 2003) and may on occasion (e.g. Shannon et al., 1989) cover a very large region

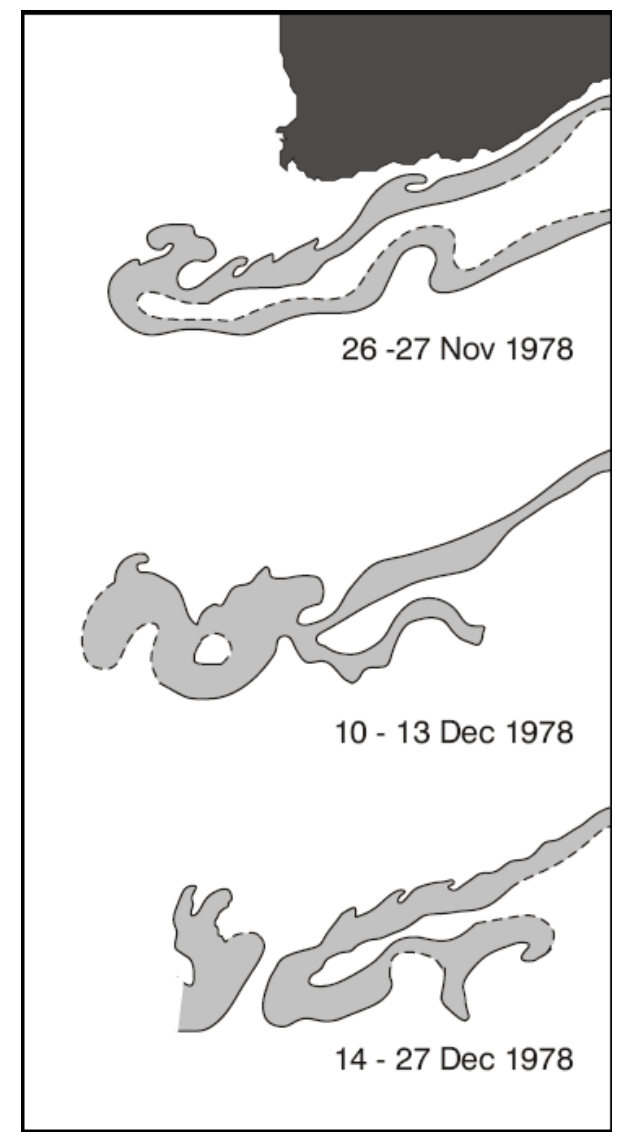

Fig. 8. A combination of outlines of the Agulhas Current for the periods shown from thermal infrared satellite imagery (after Lutjeharms and van Ballegooyen, 1988b). It shows normal progradation of the retroflection loop westwards, the occlusion of an Agulhas ring and the subsequent movement of an unattached ring into the South Atlantic Ocean.

in unusually cold water, thus potentially affecting the local weather and rainfall. This process has been evident in some models of the Agulhas Current (e.g. Boudra et al., 1989) and thus it seems to be an inherent part of the physics of ring shedding.

\section{Agulhas rings}

Agulhas rings have, when they start off, all the physical and chemical characteristics of the parent southern Agulhas Current. At the surface they have been shown to be distinguished by an annulus of warm surface water that may be up to $26^{\circ} \mathrm{C}$. Hence "ring" and not "eddy". This warm surface water rapidly loses its distinguishing temperatures due to large heat fluxes to the atmosphere (Walker and Mey, 1988). It has been shown that the upper layers of these rings may also be much affected by convective overturning due to this loss of heat (Olson et al., 1992). The bulk of these rings is however enormous and they have been judged to be the largest eddies 


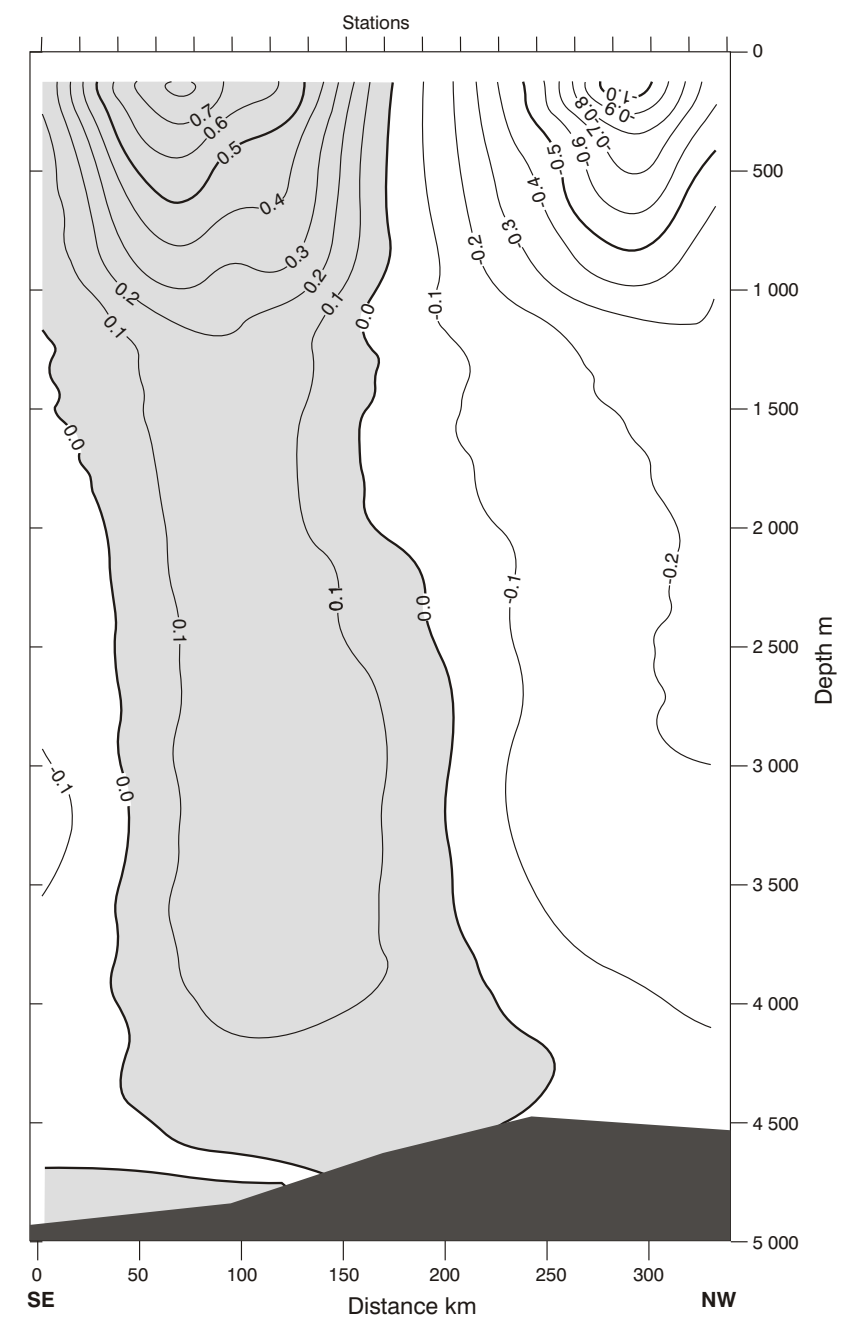

Fig. 9. A vertical speed section across an Agulhas ring, looking roughly poleward (based on Van Aken et al., 2003). The ring is at least $400 \mathrm{~km}$ in diameter and surface speed exceed $1 \mathrm{~m} / \mathrm{s}$.

in the world (Olson and Evans, 1986) based on one of the first major, directed cruises of modern times on the Agulhas Current system, the ARC (Agulhas Retroflection Cruise) of 1983. During subsequent cruises such as the MARE (Mixing in Agulhas Rings Experiment; Lutjeharms et al., 2000c) a young Agulhas ring was measured to its full depth and shown to extend all the way to the sea bottom (Fig. 9), at $4500 \mathrm{~m}$ depth (Van Aken et al., 2003). On average Agulhas rings are $240 \pm 40 \mathrm{~km}$ in diameter at the sea surface, have azimuthal speeds of between 0.29 and $0.90 \mathrm{~m} / \mathrm{s}$ in their upper layers (Duncombe Rae, 1991) and move away from their source region at a rate of about 5 to $8 \mathrm{~km} /$ day (Olson and Evans, 1986). However, the range of translation speeds of Agulhas rings has subsequently been shown to be much greater.

During the past two decades in particular it has been discovered that Agulhas rings come in a variety of shapes and sizes, behave very differently from one another and are

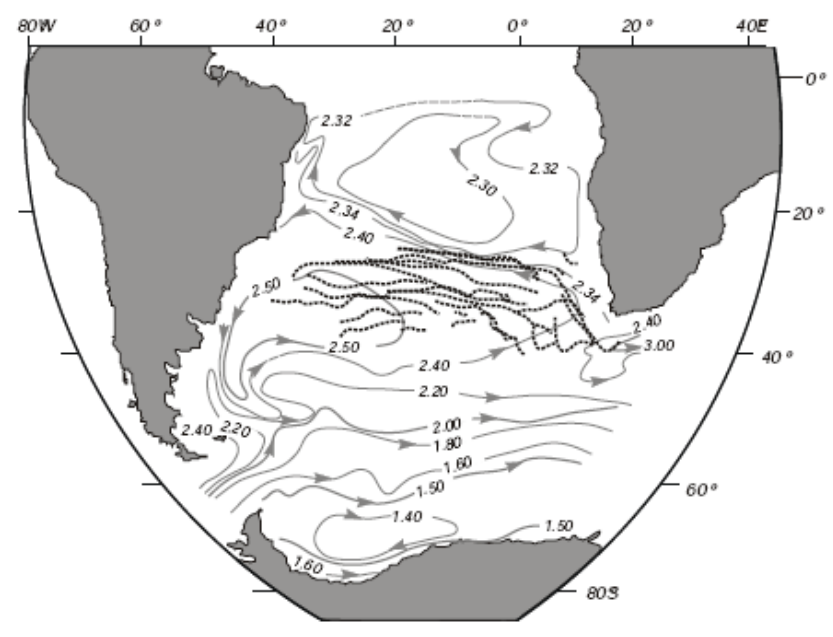

Fig. 10. The inferred movement of Agulhas rings across the South Atlantic Ocean (according to Byrne et al., 1995), shown as black dots. The feint lines show the average geostrophic background movement.

affected in different ways by the ambient waters and circulation. The values for certain kinematic characteristics given here are therefore averages within a very wide range. The Agulhas rings far from the retroflection show this very clearly (e.g. Schmid et al., 2003). Fortuitous observations by Arhan et al. (1999) in the middle of the South Atlantic Ocean have shown the very different presentation of the remains of Agulhas rings, dependent on whether they were formed in winter or in summer and how long they remained in the retroflection region where they could lose a lot of heat and moisture. Rings that are formed in winter and that do not move very rapidly equatorward, have a much deeper thermostad with considerably lower temperatures.

Once the rings have been shed, they are immersed in the cauldron of the Cape Basin west of the tip of Africa. It has recently been demonstrated that a number of rings and eddies may co-exist here at the same time and interact in different ways (Boebel et al., 2003a). A large international programme to study inter-ocean exchange south of Africa, KAPEX (Cape of Good Hope Experiment; Boebel et al., 1997), used RAFOS floats and was able to show the intense mixing of rings and surrounding water by the exchange of floats at intermediate depths. Other eddies that are found here are cyclones, smaller than the Agulhas rings and with shorter durability. A first estimate of their lifetime is about 8 months. The cyclone formed in the lee of the Agulhas Current - and discussed above - is the southernmost of these Cape basin cyclones. Their tracks in general lie at right angles to that of Agulhas rings (Boebel et al., 2003a), since they move off in a south-westerly direction. They originate at the shelf slope of south-western Africa, but why and how they are created is not yet known. Their detection and the discovery of the high degree of mixing that occurs between all mesoscale features in the Cape Basin has important implications for the manner 


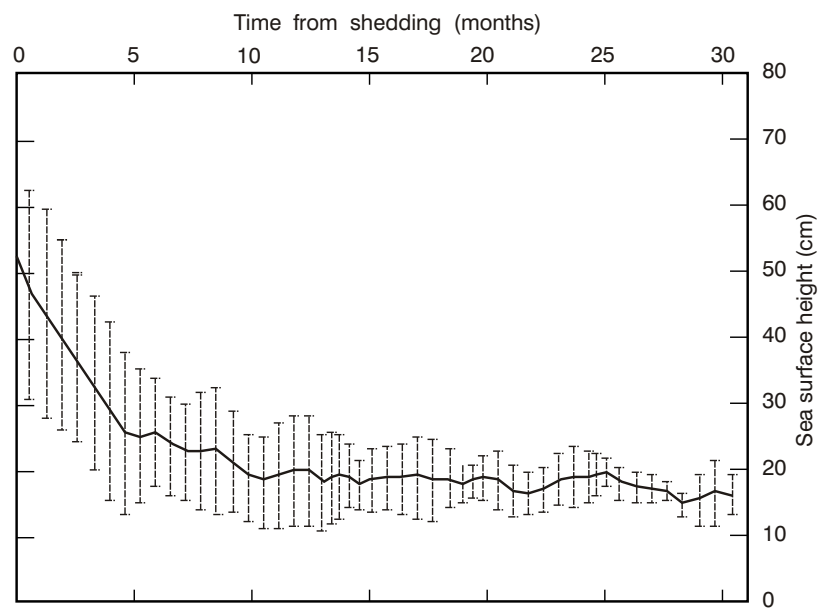

Fig. 11. Average loss of kinetic energy by Agulhas rings as they move from their origins at the Agulhas retroflection (after Schouten et al., 2000). Error bars denote standard deviations.

in which the anomalous heat and salt of these features is subsequently distributed in the Atlantic Ocean. The effect of the mixing of Agulhas rings has also been shown in other ways.

In a true pioneering investigation Byrne et al. (1995) have followed Agulhas rings in their progress across the South Atlantic Ocean using satellite altimetry (Fig. 10) and have established that they do not move north of $20^{\circ} \mathrm{S}$ and drift slightly to the left of the average background flow, as based on a compendium of historical hydrographic data. They were also able to show that they lose most of their kinetic energy very rapidly after shedding. Schouten et al. (2000) have in fact been able to demonstrate that Agulhas rings lose almost $70 \%$ of their kinetic energy within the first 5 months of their existence after which their rate of spin-down becomes much slower (Fig. 11). What is more, it has been shown that rings can split, can break up into multiple parts and that many of them never leave the Cape Basin, but dissolve totally there. Those that remain have to cross the Walvis Ridge on their way westward.

This ridge forms a major obstacle connecting the African mainland to the South Atlantic mid-ocean ridge. It can in theory be a sizeable obstruction, depending on the depth of the approaching Agulhas rings. Theoretical studies (e.g. Kamenkovich et al., 1996; Beismann et al., 1999) have shown that rings may speed up on crossing the ridge, slow down or seek a shallow part at which preferentially to cross. All of these behaviour patterns have been observed. Once Agulhas rings cross the Walvis Ridge, they are far apart (Richardson and Garzoli, 2003) and they move more closely parallel. They then do not seem to have any cyclones to contend with (Morrow et al., 2004). Only a few of them have been hydrographically observed in detail this far from their source (e.g. Arhan et al., 1999) so little is known about their further mixing.

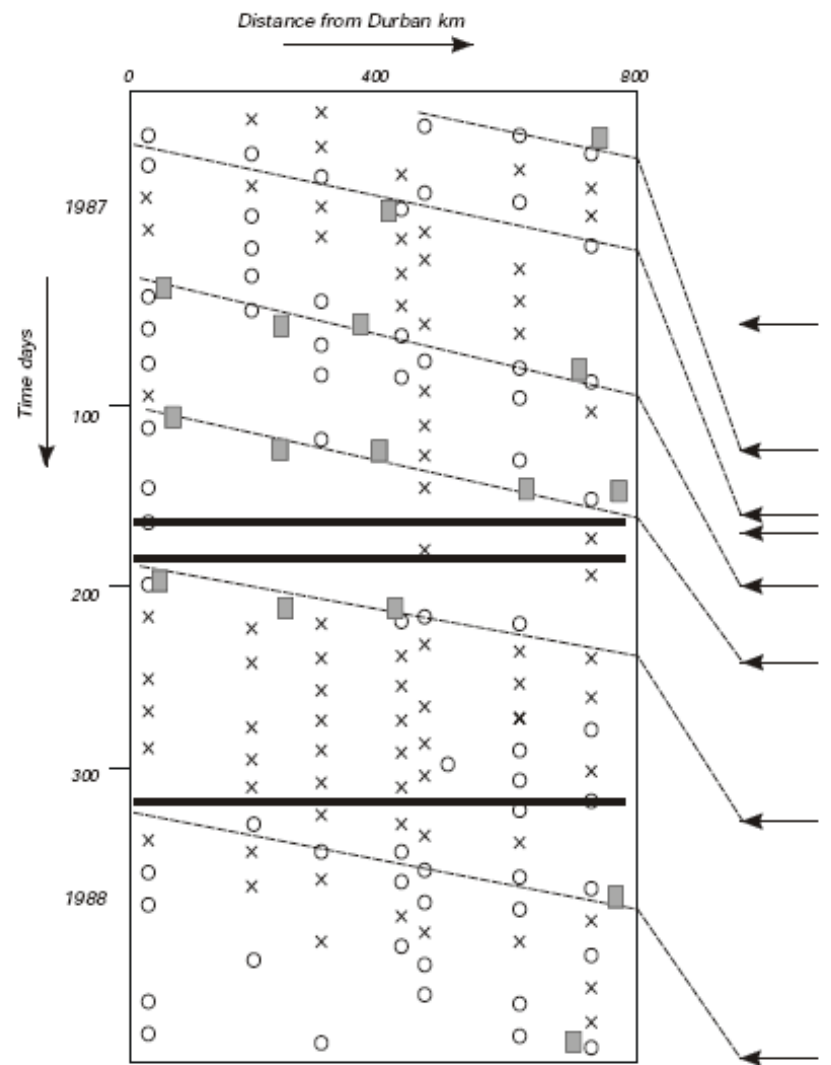

Fig. 12. The effect of Natal Pulses on the shedding of Agulhas rings (after van Leeuwen et al., 2000). This space-time diagram shows the movement of Natal Pulses downstream on the Agulhas Current as circles (altimetry from Geosat) and shaded rectangles (thermal infrared imagery from NOAA satellites); crosses denoting images for which there was no evidence of a Natal Pulse. Broken lines show the inferred movement of Natal Pulses and arrows on the right-hand border the times of the shedding of Agulhas rings.

However, studies of their mixing in the Cape Basin (e.g. Katsman et al., 2003; De Steur et al., 2004), shortly after they have been spawned, have identified a number of theoretical processes through which such mixing can occur. This has included the formation of edge filaments and other features that have not yet been observed in nature. Detailed hydrographic measurements of Agulhas rings with an undulator (Van Aken et al., 2003) have demonstrated the intense mixing that occurs at the edges of a rapidly spinning ring. There have even been a few examples of passing Agulhas rings interacting with the wind-driven, coastal upwelling regime, the Benguela upwelling system, off the west coast of southern Africa. Upwelling filaments off this coast can extend some distance from the coast (e.g. Lutjeharms and Stockton, 1987; Shillington et al., 1990) and thus reach the general corridor along which Agulhas rings are wont to pass. They may then encircle rings. In extreme cases, especially when there is a strong berg wind - an offshore movement of air from the 


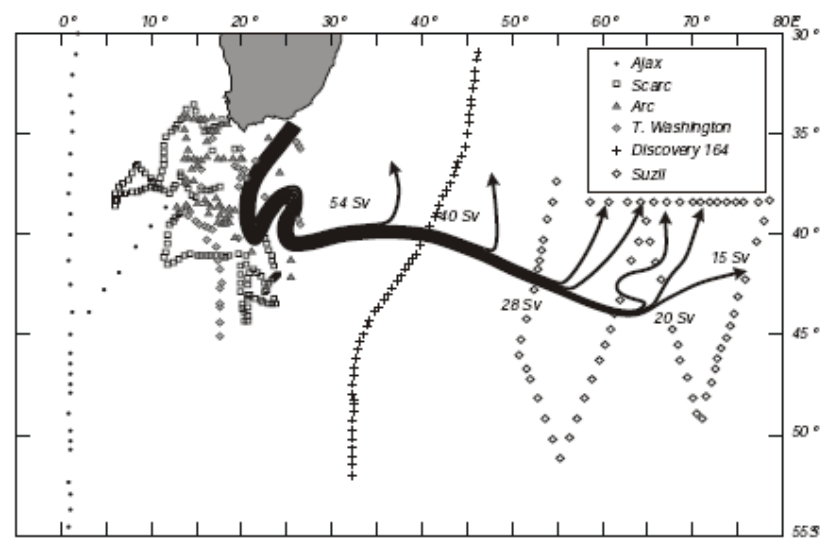

Fig. 13. The trajectory and volume flux of the Agulhas Return Current based on a collection of hydrographic data collected over the past few decades (after Lutjeharms and Ansorge, 2001). The cruises from which these data derive are given in the inset. By $65^{\circ} \mathrm{E}$ the current has all but petered out.

higher continental escarpment - such interaction may result in upwelling filaments being drawn up to $1000 \mathrm{~km}$ offshore (Lutjeharms et al., 1991).

The question remains: what processes trigger the shedding of an Agulhas ring? Could it be a natural consequence of the extreme extension of the Agulhas retroflection loop (e.g. Lutjeharms, 1988a)? Or could passing Natal Pulses cause a short circuit between the Agulhas Current and the Agulhas Return Current? As mentioned above, a careful analysis by van Leeuwen et al. (2000) has suggested an answer (Fig. 12). They have shown that over a period of two years 6 Natal Pulses were formed. These moved downstream at a very steady rate of $20 \mathrm{~km} /$ day up to a distance of $800 \mathrm{~km}$ from Durban where they reached the edge of the wide shelf south of Africa (viz. Fig. 1), the Agulhas Bank. Here shear eddies and persistent cloudiness complicated efforts to follow individual Natal Pulses, but taking a cue from Lutjeharms and Roberts (1988), it was assumed that once along the edge of the Agulhas Bank the progress of Natal Pulses would slow to $5 \mathrm{~km} /$ day. On this basis it has then been shown (Fig. 12) that each Natal Pulse caused the shedding of an Agulhas ring when it reached the Agulhas retroflection. This result has also subsequently been confirmed by studies by both Schouten et al. (2002a) and Lutjeharms et al. (2003b). However, the results portrayed in Fig. 12 also show that during these years there was at least one occasion on which a ring was formed without the intervention of a Natal Pulse. The most important aspect of the spawning of rings is the interocean exchange brought about in this way.

What has been learnt over the past decades on the interocean exchange south of Africa has been ably summarised by de Ruijter et al. (1999b). Leakage into the South Atlantic seems to come in three forms: direct leakage, Agulhas filaments and Agulhas rings. Gordon et al. (1987) have esti- mated a very high volume flux of $10 \mathrm{~Sv}$ relative to $1500 \mathrm{db}$ for direct leakage on one occasion, but this seems to have been exceptional. Such leakage may move across the Agulhas Bank and not be directly involved in the Agulhas Current or its products such as Agulhas filaments. Transport of only $0.1 \mathrm{~Sv}$ was estimated for Agulhas filaments (Lutjeharms and Cooper, 1996). By far the greatest leakage takes place via the shedding of rings. Garzoli and Goni (2000) have established that the flow across the Cape Basin may consist of 50\% Indian Ocean water, but this percentage varies dramatically from year to year. Probably the best estimate of inter-ocean exchange brought about by Agulhas rings has given a volume flux of $7 \mathrm{~Sv}$ for water warmer than $8^{\circ} \mathrm{C}$, a heat flux of $0.9 \mathrm{PW}$ and a salt flux of $78 \times 10^{12} \mathrm{~kg} / \mathrm{year}$ (Van Ballegooyen et al., 1994). However, the inter-annual range in these values is large. That part of the southern Agulhas Current that negotiates the Agulhas retroflection unscathed moves eastwards as the Agulhas Return Current.

\section{Agulhas Return Current}

The path of the Agulhas Return Current and its volume flux is shown in Fig. 13. Two important characteristics of the current immediately stand out. First, the current exhibits extensive meanders south of Africa. Second, the volume transport of the current diminishes along its path as Agulhas water leaks into the South-West Indian Ocean subgyre. The velocity structure of the Agulhas Return Current near the retroflection is shown in Fig. 14.

The width of the current as well as its vertical structure here still bears a strong resemblance to that of the Agulhas Current proper (viz. Beal and Bryden, 1999), as may have been expected. Overall the velocities are nevertheless somewhat reduced. In the southern Agulhas Current surface speeds of up to $2 \mathrm{~m} / \mathrm{s}$ may be found. A volume transport of about $55 \mathrm{~Sv}$ to a depth of $1500 \mathrm{~m}$ has been estimated for the Agulhas Return Current here. The total vertical extent of the Agulhas Return Current has as yet not been measured.

The Agulhas Return Current flows along the Subtropical Convergence south of Africa. This front has been shown to exhibit one of the most strongly developed meridional gradients in temperature and salinity (e.g. Lutjeharms and Valentine, 1984); a $6^{\circ} \mathrm{C}$ drop in temperature over a distance of $20 \mathrm{~km}$ being not unknown. The current does not always follow the front closely thus leading to a double front of which the northern one has then been called the Agulhas Front (e.g. Belkin and Gordon, 1996). This front, as could be expected, has been shown (Kostianoy et al., 2004) to extend no further than about $75^{\circ} \mathrm{E}$, the longitude at which the Agulhas Return Current has also died out based on estimates of its volume transport, its geostrophic velocity as well as its Agulhas Current water characteristics (Lutjeharms and Ansorge, 2001). This same zonal limit is also evident in the distribution of mesoscale turbulence as inferred from the variability of sea 
surface height (e.g. Cheney et al., 1983). Last, but by no means least, the zone in which the Agulhas Return Current is found exhibits high concentrations of chlorophyll-a (e.g. Lutjeharms et al., 1986b; Weeks and Shillington, 1996). This strong signal also stops at a longitude of about $70^{\circ} \mathrm{E}$. The relationship between mesoscale variability and high primary productivity has been demonstrated to come about by the increased event-scale productivity in eddies at the Subtropical Convergence (Llido et al., 2005). One can therefore assume with some confidence that the Agulhas Return Current terminates between 70 and $80^{\circ} \mathrm{E}$ and that the subsequent eastward flow is the South Indian Ocean Current (Stramma, 1992). Why should there be this increase in mesoscale turbulence along the path of the Agulhas Return Current?

Many observations across and at the Subtropical Convergence south of Africa during the past few decades have shown the prevalence of eddies of various dimensions here (Lutjeharms and Valentine, 1988a). These eddies come in various shapes and sizes and are believed to be largely due to the shear instability induced by the Agulhas Return Current juxtaposed with the Subtropical Convergence. Cold eddies are shed on the equatorward side, whereas warm eddies may be taken up by the cold waters south of the Subtropical Convergence (Lutjeharms, 1988b). If not totally dissipated it is believed that both sets of eddies drift back towards the parent front in line with their vorticity. Studies with RAFOS floats (Boebel et al., 2003b) during the 1990s have indicated that such eddies may move westward after having been shed; this agrees with findings of meanders in the Subtropical Convergence that tend to move westward (Weeks and Shillington, 1996). The origin of these meridional meanders has been adequately described.

Figure 13 shows in elementary terms the major meander in the Agulhas Return Current. It has also been described using drifters (Gründlingh, 1978) and satellite imagery (Lutjeharms and Valentine, 1988b). The cause of this meander is a major obstruction in the path of the eastward movement of water in the Agulhas Return Current, the shallow Agulhas Plateau. Downstream of the Agulhas Plateau the extension of the Mozambique Plateau may cause a secondary meander (Harris, 1970; Gründlingh, 1978) for the same reason. Modelling the current in a number of ways (e.g. Lutjeharms and van Ballegooyen, 1984; Boudra et al., 1989; Matano, 1996) all show the decisive influence of the bottom topography on the path of the Agulhas Return Current. Suggestions that the meanders so caused will persist as a wave of diminishing amplitude to the east (Pazan and Niiler, 2004) have still to be proven.

The Agulhas Return Current forms an outflow from the greater Agulhas Current system; the sources of the Agulhas Current form the inflow.

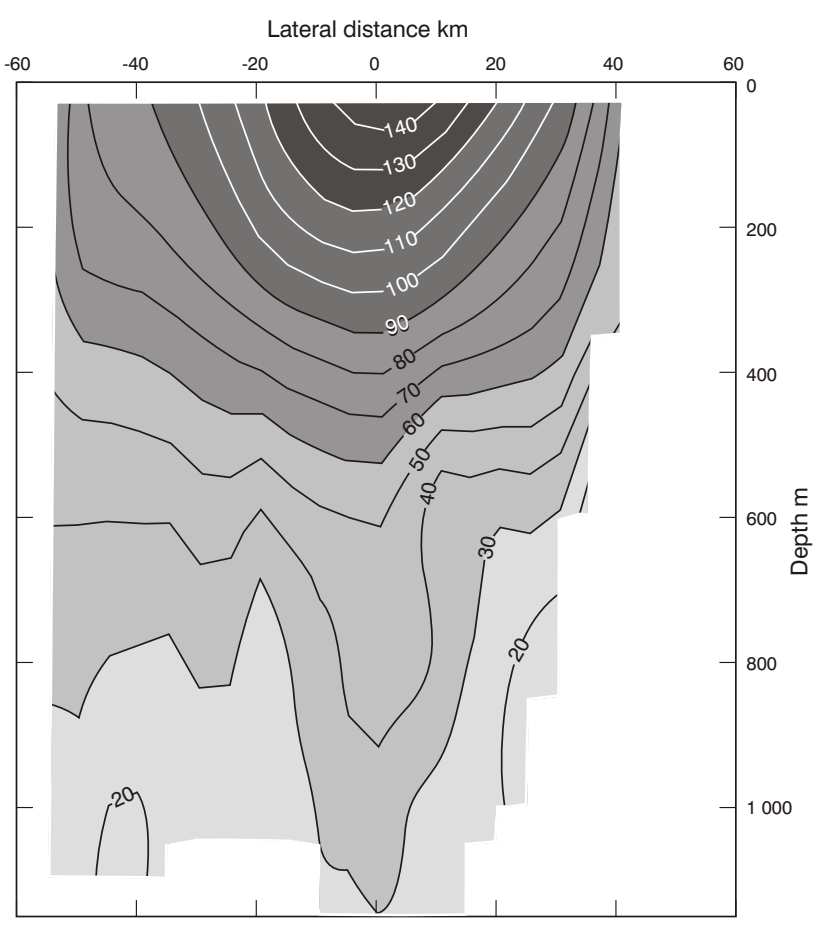

Fig. 14. A vertical speed section across the Agulhas Return Current based on observations with RAFOS floats at intermediate depths combined with acoustic Doppler current meter readings in the upper $400 \mathrm{~m}$ (after Boebel et al., 2003b). Speeds given are in $\mathrm{cm} / \mathrm{s}$ and are in the downstream direction.

\section{Sources of the Agulhas Current}

Classically, as seen in most atlases and text books, the Agulhas Current is a straightforward extension of an upstream western boundary current, the Mozambique Current (e.g. Fig. 1). The other tributary has been portrayed as water flowing directly from the southern limb of the East Madagascar Current into the Agulhas Current at a latitude of about $30^{\circ} \mathrm{E}$ (e.g. Michaelis, 1923; Paech, 1926). These early interpretations were based on observations of ships' drift and on occasional observations of sea surface temperatures. Modern analyses of such data (Lutjeharms et al., 2000d) and of historical hydrographic data (Harris, 1972) allow much the same interpretation, as do early numerical models (e.g. Luther and O'Brien, 1989). However, a careful analysis of all historical hydrographic data available at the time has shown (Sætre and Jorge da Silva, 1984) that the circulation in the Mozambique Current might be considerably more complicated than a simple western boundary current. Altimetric observations have incongruously indicated (e.g. Gordon et al., 1983) that the Mozambique Channel is a region of high levels of variability, in conflict with the concept of a neat western boundary current. This conundrum has been removed by dedicated observations in the channel during the ACSEX (Agulhas Current Sources Experiment) programme of the past ten years (De Ruijter et al., 2006). 


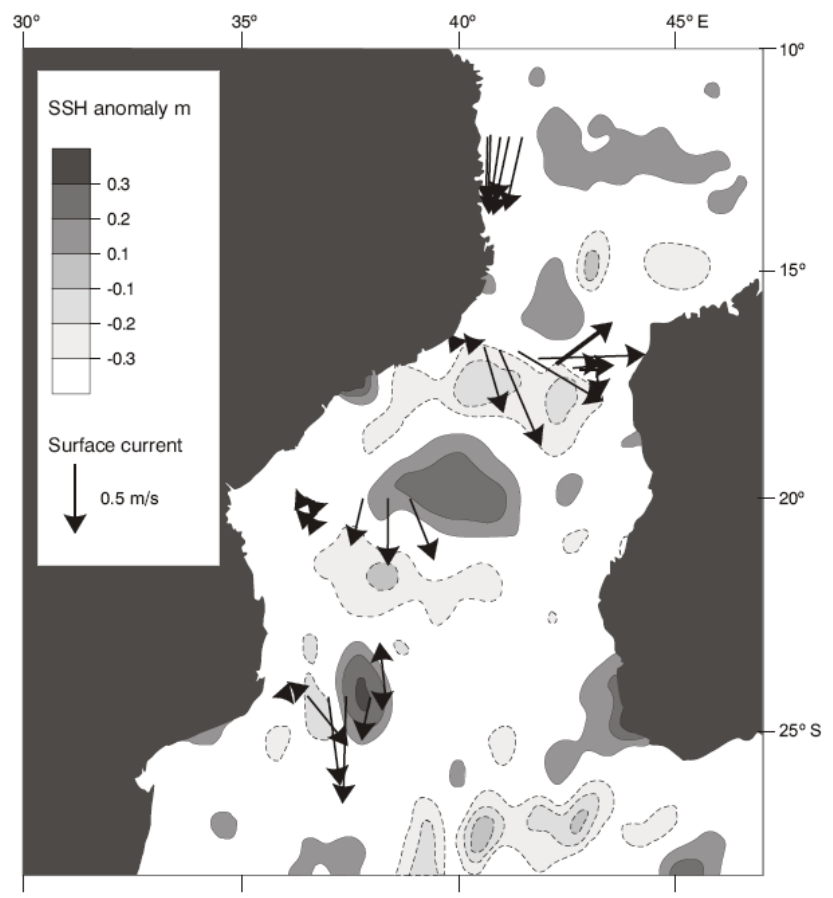

Fig. 15. The flow regime in the Mozambique Channel during the ACSEX I cruise of March-April 2000 (according to De Ruijter et al., 2002). Grey shades indicate sea surface height anomalies. Currents represent those measured over the top $200 \mathrm{~m}$ of the water column.

In Fig. 15 the results of the first cruise of this programme are shown (De Ruijter et al., 2002). Instead of a continuous current, a street of anti-cyclonic eddies drifting southward was found. From satellite altimetry it was furthermore established that these eddies are a persistent and inherent part of the flow regime in the Mozambique Channel (Schouten et al., 2003). They are formed near the narrows of the channel (Ridderinkhof and de Ruijter, 2003), are oligotrophic - in contrast to the otherwise fairly chlorophyll-rich ambient water masses of the Mozambique Channel - and interact with the shelf waters by drawing out filaments from them. It has been shown that they follow a fairly constrained path along the western side of the channel, eventually moving parallel and fairly close to the Agulhas Current. During their southward movement they steadily increase in energy, as presented in sea surface height anomalies. Eddies have also been observed in the eastern Mozambique Channel (Quartly and Srokosz, 2004), but these have been assumed to come from south of Madagascar.

Persistent and intense lee eddies have furthermore been found in offsets of the Mozambican coastline, such as in the Delagoa Bight (Lutjeharms and Jorge da Silva, 1988) and south of Angoche. These eddies cannot be considered entirely peripheral compared to the major flow regime; they may in fact play an important role in the ecosystem of the region. Nehring et al. (1987) have for instance shown that by

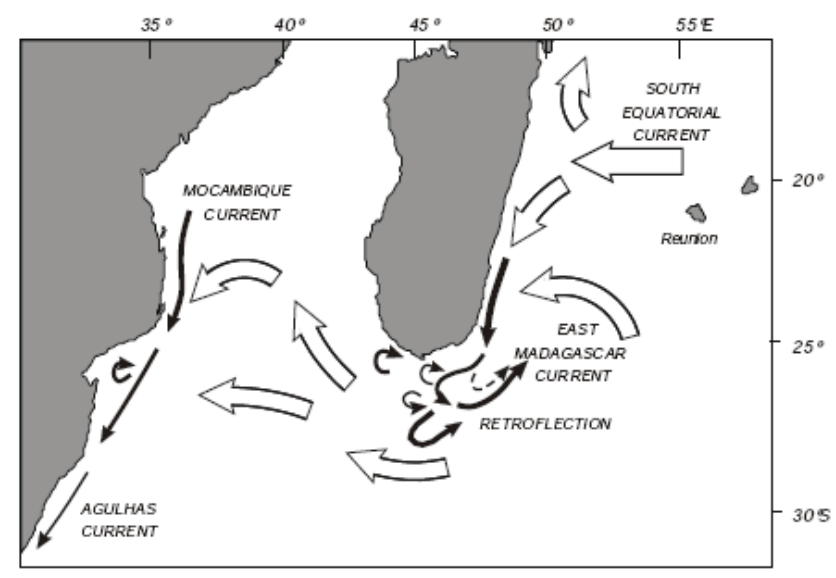

Fig. 16. A conceptual image of the inferred movement of water in the vicinity of the southern tip of Madagascar (after Lutjeharms et al., 1981). Open arrows denote wide, slow flow while the intense flow of the southern limb of the East Madagascar Current and of the Agulhas Current are shown by solid arrows. The well defined Mozambique Current in this conceptual picture has subsequently been shown to be a wrong interpretation of contemporary data.

far the highest values of chlorophyll-a in the channel are to be found in the Angoche lee eddy. Finer resolution modelling of the region (e.g. Biastoch and Krauss, 1999; Chapman et al., 2003) has simulated the creation of Mozambique eddies admirably. With the advent of the ACSEX and LOCO (Long Term Ocean Climate Observations) (De Ruijter et al., 2006) during the past decade, knowledge and understanding of the circulation in the Mozambique Channel has thus been revolutionised. Regrettably this is not yet the case for the other supposed tributary to the Agulhas Current, the southern limb of the East Madagascar Current.

The East Madagascar Current has been shown to be a small western boundary current fed largely by the South Equatorial Current. At a latitude of about $17^{\circ} \mathrm{S}$ this zonal inflow from the east splits to form the northern (Swallow et al., 1988) and the southern limb of the East Madagascar Current (Fig. 16). First dedicated hydrographic observations of the termination of the southern limb of the East Madagascar Current in the 1960s showed no evidence of a direct connection to the Agulhas Current; the waters south of Madagascar on this occasion actually moving eastward (Lutjeharms et al., 1981). Subsequent studies using satellite observations and the tracks of drifters (e.g. Lutjeharms, 1988c, d; Quartly and Srokosz, 2002) have given strong indications that the current retroflects, with most of its water being returned eastward (Fig. 16). Other studies (e.g. De Ruijter et al., 2003) suggest that the termination of the southern limb of the East Madagascar Current may on occasion be in the form of a free westward jet, generating vortex dipoles south of the Mozambique Channel. These dipoles are clearly seen in satellite observations of ocean colour since the northern cyclones that form 


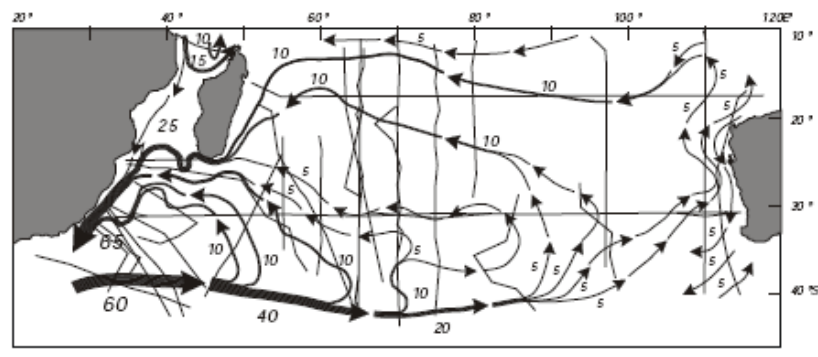

Fig. 17. A portrayal of the volume transport in the South-West Indian Ocean subgyre. The calculated baroclinic transport is for the upper $1000 \mathrm{~m}$ and is given in Sverdrup (after Stramma and Lutjeharms, 1997). Thin lines represent the lines of hydrographic stations on which these calculations are based.

part of these vortex pairs carry largely shelf water from south of Madagascar. On this shelf there is a coastal upwelling cell (DiMarco et al., 2000; Machu et al., 2003) that has been shown to be driven by the strong adjacent current and not by the prevailing winds (Lutjeharms and Machu, 2000).

The third, but by far the largest contributor to the flow of the Agulhas Current has been shown to be recirculation in a South-West Indian Ocean subgyre (Fig. 17). Whereas the volume transport in the upper $1000 \mathrm{~m}$ through the Mozambique Channel is here shown to be only $5 \mathrm{~Sv}$ and that estimated from the southern limb of the East Madagascar Current $20 \mathrm{~Sv}$, at best, the flux that comes from the recirculation is $40 \mathrm{~Sv}$. Of this $40 \mathrm{~Sv}$ at least $35 \mathrm{~Sv}$ peels off the Agulhas Return Current west of $70^{\circ} \mathrm{E}$, as was mentioned before when discussing this current. These three sources of the Agulhas Current proper do not only contribute volume flux, but have been shown to have some important controlling effects on the behaviour of the current.

Mozambique eddies moving poleward from the Mozambique Channel have been shown to get adsorbed onto the seaward border of the Agulhas Current (Schouten et al., 2002a; De Ruijter et al., 2005), to then trigger a Natal Pulse that subsequently brings about the shedding of an Agulhas ring at the Agulhas Current retroflection. Mozambique eddies have therefore been surmised as being a factor that controls interocean exchange south of Africa. The frequency with which these Mozambique eddies are formed may in turn be controlled by Rossby waves travelling zonally across the South Indian Ocean (Schouten et al., 2002b; De Ruijter et al., 2005) and these waves may have their primary origin in seasonal wind stress changes in the Arabian Sea. A second stimulus for Natal Pulse generation may be eddies coming from the east. At least one case of such a trigger from the east has been found to date (T. Lamont, personal communication).

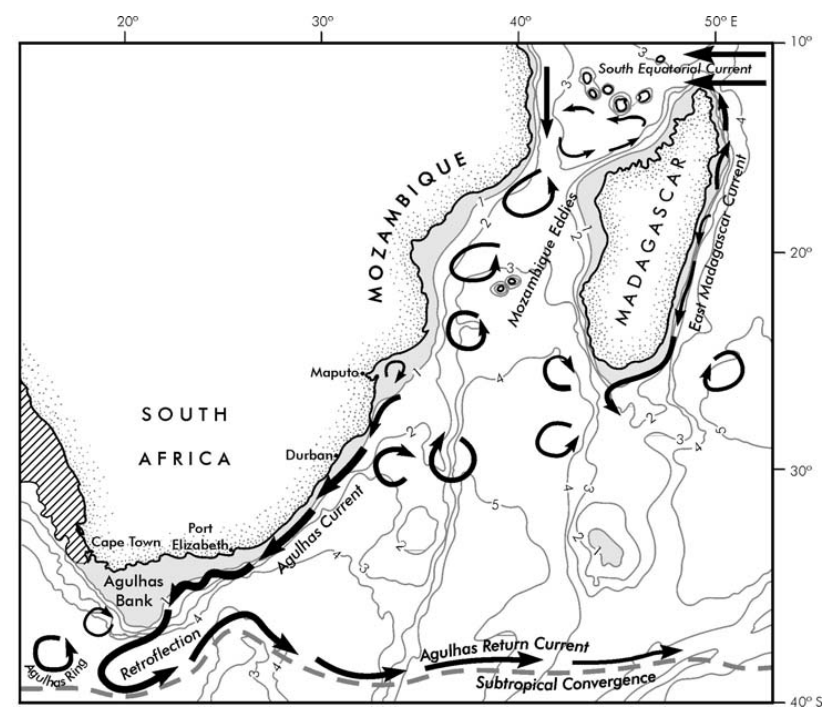

Fig. 18. A conceptual portrayal of the flow patterns in the greater Agulhas Current (after Lutjeharms, 2006a) as they are currently understood. In order to assess what has been learnt about this system over the past three decades, a comparison between this figure and Fig. 1 should be very instructive.

\section{Conclusions}

A pictorial presentation of current understanding on the greater Agulhas Current system is given in Fig. 18. When compared to Fig. 1 it is clear how much has been learnt during the past 30 years.

First, the southern termination of the Agulhas Current has been studied intensively and the retroflection of the current and the ring shedding process established in considerable detail. The subsequent behaviour of Agulhas rings and the manner in which they disperse their load of salt and heat in the South Atlantic Ocean has also been studied extensively. It has been demonstrated that this insertion of heat and salt contributes to the meridional overturning of the Atlantic Ocean as a whole. This heat dispersal is highly dependent on the interaction of the water in the Agulhas Current or in its rings with the overlying atmosphere. An extensive and protracted investigation has made a major contribution to current understanding of the processes involved in such sea-air interaction. In fact, the influence of the warm waters of the Agulhas Current and sea surface temperature anomalies in general on the weather and climate of the adjacent subcontinent has become and remains a major field of investigation.

A major advance has been made in determining the nature of the supposed tributaries of the Agulhas Current, namely the flow through the Mozambique Channel, from east of Madagascar and in the South Indian Ocean gyre. The discovery that no western boundary current exists in the Mozambique Channel has been a major advance. A look at Fig. 1 clearly shows the ignorance on these currents that existed in the early 1970 s. 
Of particular importance has been the identification of those aspects of the Agulhas Current that make it unique as a western boundary current. This has included the distinguishing characteristics of the southern and the northern Agulhas Current and in particular the extraordinary path stability of the northern component of this current. The discovery of the Natal Pulse, the eddies that may trigger it, the influence it has on Agulhas ring shedding and the impact it may thus have on inter-ocean water exchanges when it forces an upstream retroflection, all these have contributed substantially to a better understanding of the mechanics of the system.

Modelling of the system has also advanced rapidly and simulations are increasingly realistic. In many cases models suggest certain processes the trustworthiness of which cannot currently be verified because of a lack of data. So what are the main processes that remain poorly understood?

The flow patterns in the Mozambique Channel as a whole still are not well known, particularly in the Comores Basin in the northern mouth of the channel as well as the whole eastern side, where there are regions that have never been hydrographically surveyed at all. The East Madagascar Current has never been properly surveyed as a unit and its supposed retroflection has not been investigated adequately. Our current knowledge on the Agulhas Return Current is similarly based on a collection of non-synoptic hydrographic surveys of varying quality. In all of these cases dedicated, multidisciplinary cruises would seem the best way to remove part of existing ignorance. The finding that mesoscale features such as eddies trigger Natal Pulses and thus may control the globally important inter-ocean exchanges south of Africa was totally unexpected, but much more needs to be done to properly understand how this comes about. When looking at the system on the sub-mesoscale, the number of research questions abounds even more.

What drives the coastal upwelling off south-eastern Madagascar? What impact does the Angoche lee eddy have on its direct environment? What influence do the passing Mozambique eddies have on the Delagoa Bight eddy? Since sediment patterns on the shelf north of Richards Bay indicate northward flow, where does the Agulhas Current actually start? What is the effect of the St. Lucia upwelling cell on the water masses of the Natal Bight? Is the seasonal thermocline on the Agulhas Bank largely driven by the cold water coming from the Port Alfred upwelling cell? How constant is the presumed inflow of cold bottom water at the Port Alfred upwelling cell? What role do shear edge filaments of the southern Agulhas Current play in the heat budget of the waters of the Agulhas Bank? Where do Cape Basin cyclones come from and what causes their formation? The list seems endless and largely subjective. Nevertheless, dedicated cruises seem to be called for here as well, but in many cases longer term monitoring with appropriately placed current meter moorings would be essential for a proper understanding of the underlying processes. The breadth and depth of fundamental questions on the greater Agulhas Current sys- tem that can now be asked is itself an artefact of the progress that has been made on the understanding of the system. This raises the question why such progress was made in the first place. This might indicate how to proceed efficaciously in future. A number of factors stand out particularly clearly.

First, in a region far away from the main centres of shipgoing oceanographic research the advent of readily available satellite remote sensing has been the cause of an observational revolution. Since the southern parts of the Agulhas Current are thermally strongly identifiable at the sea surface, thermal infrared imagery was a decided boon to early investigations (e.g. Lutjeharms, 1981). Subsequent access to the first remotely sensed ocean colour from satellite (Shannon, 1979) and more recently to the SeaWiFS (Sea-viewing Wide Field Sensor) has added to this enormous benefit for studying the Agulhas Current system (e.g. Weeks and Shillington, 1996). These means of observing, particularly in the thermal infrared, have limited uses in regions where there are no substantial temperature or colour contrasts at the sea surface or where there is persistent cloud cover. The latter problem has been largely removed with the introduction of microwave observations (Rouault and Lutjeharms, 2003) and both with altimetric observations (Gründlingh, 1988). The latter has lead to what may be considered a second revolution in studies of the Agulhas Current system. It is not only this availability of new observational technologies that has facilitated this stupendous growth in knowledge on the Agulhas Current system, but also the international recognition of the global importance of the system.

One of the first to recognise this was Gordon (e.g. 1985, 1986) who organised one of the first major modern cruises in the region, the aforementioned ARC (Agulhas Retroflection Cruise) in 1983. This was followed by the SCARC (Subtropical Convergence and Agulhas Retroflection Cruise; Lutjeharms, 1987), the KAPEX (Cape of Good Hope Experiment; Boebel et al., 1997), the MARE (Mixing in Agulhas Rings Experiment; Lutjeharms et al., 2000c) and the ACSEX (Agulhas Current Sources Experiment; De Ruijter et al., 2006), all large scale observational programmes dedicated to a better understanding of components of the greater Agulhas Current. The BEST (Benguela Sources and Transport; Pillsbury et al., 1994) project was based on current meter moorings in the South Atlantic Ocean in the path of Agulhas rings as is the ASTTEX (Agulhas-South Atlantic Thermohaline Transport Experiment). The ACE (Agulhas Current Experiment; Beal and Bryden, 1999) consisted of current meter placements in the Agulhas Current proper. This broad international interest and participation has helped to lift the study of the Agulhas Current onto a new level. What does this suggest for the future?

A number of international programmes are being planned to address some of the questions mentioned above, as are a number of modelling projects aimed specifically at the Agulhas Current system. A particular requirement will be to study some of the important adjacent shelves and the interaction of 
the offshore currents with these. This could start soon as part of the ASCLME (Agulhas and Somali Current Large Marine Ecosystem) project. Prediction of future developments is fraught with obvious problems and limitations, but it is difficult to imagine the same number of fundamental discoveries on the greater Agulhas Current being made during the next few decades as have been made during the past three.

Acknowledgements. This review closely follows the contents of the Fridtjof Nansen Medal Lecture held at the annual general assembly of the European Geosciences Union in Vienna in 2006. I thank the medal committee who thought it fit to award me this distinction and for those overly generous souls who nominated me. It came at a personally difficult time and was therefore all the more appreciated. I am particularly grateful to W. de Ruijter of the University of Utrecht, A. Gordon of Columbia University, T. Rossby of the University of Rhode Island, O. Boebel of the Alfred Wegener Institute for Polar and Marine Research and a host of other colleagues such as R. van Ballegooyen, H. Valentine and I. Ansorge for collaboration over many years that has substantially enhanced my own modest contribution to progress on our understanding of the greater Agulhas Current system and made it a lot of fun. Due to length limitations I have regrettably had to leave out of this survey a large number of valuable contributions, something that will be obvious to anybody knowledgeable about the system. This omission is corrected by a much more detailed and in depth overview of what is currently known about the greater Agulhas Current that is to be found in the book "The Agulhas Current" (Lutjeharms, 2006b; Springer-Verlag, Berlin).

Edited by: J. M. Huthnance

\section{References}

Anderson, F. P., Gründlingh, M. L., and Stavropoulos, C. C.: Kinematics of the southern Natal coastal circulation: some historic measurements 1962-63, S. Afr. J. Sci., 84, 857-860, 1988.

Arhan, M., Mercier, H., and Lutjeharms, J. R. E.: The disparate evolution of three Agulhas rings in the South Atlantic Ocean, J. Geophys. Res., 104, 20 987-21 005, 1999.

Bang, N. D.: Major eddies and frontal structures in the Agulhas Current retroflexion (sic) area in March, 1969, in: Symposium "Oceanography South Africa 1970", South African National Committee for Oceanographic Research, 16 pp., 1970a.

Bang, N. D.: Dynamic interpretations of a detailed surface temperature chart of the Agulhas Current retroflexion (sic) and fragmentation area, S. Afr. geogr. J., 52, 67-76, 1970 b.

Bang, N. D.: Characteristics of an intense ocean frontal system in the upwell regime west of Cape Town, Tellus, 25, 256-265, 1973a.

Bang, N. D.: Oceanography: Oceanographic Environment of Southern Africa, in: Standard Encyclopaedia of Southern Africa, edited by: Spies, J. J. and du Plessis, P. C., vol. 8, Nasou, Cape Town, pp. 282-286, 1973 b.

Beal, L. M. and Bryden, H. L.: Observations of an Agulhas Undercurrent, Deep-Sea Res. I, 44, 1715-1724, 1997.

Beal, L. M. and Bryden, H. L.: The velocity and vorticity structure of the Agulhas Current at $32^{\circ} \mathrm{S}$, J. Geophys. Res., 104, 5151$5176,1999$.
Beckley, L. E.: Sea-surface temperature variability around Cape Recife, South Africa, S. Afr. J. Sci., 79, 436-438, 1983.

Beismann, J.-O., Käse, R. H., and Lutjeharms, J. R. E.: On the influence of submarine ridges on translation and stability of Agulhas rings, J. Geophys. Res., 104, 7897-7906, 1999.

Biastoch, A. and Krauss, W.: The role of mesoscale eddies in the source regions of the Agulhas Current, J. Phys. Oceanogr., 29, 2303-2317, 1999.

Boebel, O., Duncombe Rae, C., Garzoli, S., Lutjeharms, J., Richardson, P., Rossby, T., Schmid, C., and Zenk, W.: Float experiment studies interocean exchanges at the tip of Africa, Eos, Trans. Am. geophys. Un., 79(1), 7-8, 1997.

Boebel, O., Lutjeharms, J., Schmid, C., Zenk, W., Rossby, T., and Barron, C.: The Cape Cauldron: a regime of turbulent interocean exchange, Deep-Sea Res. II, 50, 57-86, 2003 a.

Boebel, O., Rossby, T., Lutjeharms, J., Zenk, W., and Barron, C.: Path and variability of the Agulhas Return Current, Deep-Sea Res. II, 50, 35-56, 2003b.

Belkin, I. M. and Gordon, A. L.: Southern Ocean fronts from the Greenwich meridian to Tasmania, J. Geophys. Res., 101, 36753696, 1996.

Boudra, D. B., Maillet, K. A., and Chassignet, E. P.: Numerical modeling of Agulhas retroflection and ring formation with isopycnal outcropping, in: Meso-scale/Synoptic Coherent Structures in Geophysical Turbulence, edited by: Nihoul, J. C. J. and Jamart, B. M., Elsevier, Amsterdam, pp. 315-335, 1989.

Boyd, A. J., Tromp, B. B. S., and Horstman, D. A.: The hydrology of the South African south-western coast between Cape Point and Danger Point in 1975, S. Afr. J. Mar. Sci., 3, 145-168, 1985.

Boyd, A. J., Taunton-Clark, J., and Oberholster, G. P. J.: Spatial features of the near-surface and midwater circulation patterns off western and southern South Africa and their role in the life histories of various commercially fished species, S. Afr. J. Mar. Sci., 12, 189-206, 1992.

Byrne, D. A., Gordon, A. L., and Haxby, W. F.: Agulhas Eddies: a synoptic view using Geosat ERM data, J. Phys. Oceanogr., 25, 902-917, 1995.

Carter, R. and d'Aubrey, J.: Inorganic nutrients in Natal continental shelf waters, in: Coastal Ocean Studies off Natal, South Africa, edited by: Schumann, E. H., Lecture Notes on Coastal and Estuarine Studies 26, Springer-Verlag, Berlin, pp. 131-151, 1988.

Carter, R. A. and Schleyer, M. H.: Plankton distributions in Natal coastal waters, in: Coastal Ocean Studies off Natal, South Africa, edited by: Schumann, E. H., Lecture Notes on Coastal and Estuarine Studies 26, Springer-Verlag, Berlin, pp. 152-177, 1988.

Chapman, P., DiMarco, S. F., Davis, R. E., and Coward, A. C.: Flow at intermediate depths round Madagascar based on ALACE float trajectories, Deep-Sea Res. II, 50, 1957-1986, 2003.

Cheney, R. A., Marsh, J. G., and Beckley, B. D.: Global mesoscale variability from collinear tracks of SEASAT altimeter data, J. Geophys. Res., 88, 4343-4354, 1983.

Christensen, M. S.: Sea-surface temperature charts for Southern Africa, south of $26^{\circ}$ S, S. Afr. J. Sci., 76, 541-546, 1980.

Crimp, S. J., Lutjeharms, J. R. E., and Mason, S. J.: Sensitivity of a tropical-temperate trough to sea-surface temperature anomalies in the Agulhas retroflection region, Water SA, 24, 93-101, 1998.

De Ruijter, W.: Asymptotic analysis of the Agulhas and Brazil Current systems, J. Phys. Oceanogr., 12, 361-373, 1982. 
De Ruijter, W. P. M. and Boudra, D. B.: The wind-driven circulation in the South Atlantic-Indian Ocean - I. Numerical experiments in a one-layer model, Deep-Sea Res., 32, 557-574, 1985.

De Ruijter, W. P. M., van Leeuwen, P. J., and Lutjeharms, J. R. E.: Generation and evolution of Natal Pulses: solitary meanders in the Agulhas Current, J. Phys. Oceanogr., 29, 3043-3055, 1999a.

De Ruijter, W. P. M., Biastoch, A., Drijfhout, S. S., Lutjeharms, J. R. E., Matano, R. P., Pichevin, T., van Leeuwen, P. J., and Weijer, W.: Indian-Atlantic inter-ocean exchange: dynamics, estimation and impact, J. Geophys. Res., 104, 20 885-20 911, 1999b.

De Ruijter, W. P. M., Ridderinkhof, H., Lutjeharms, J. R. E., Schouten, M. W., and Veth, C.: Observations of the flow in the Mozambique Channel, Geophys. Res. Lett., 29, 1401-1403, 2002.

De Ruijter, W. P. M., van Aken, H. M., Beier, E. J., Lutjeharms, J. R. E., Matano, R. P., and Schouten, M. W.: Eddies and dipoles around South Madagascar: formation, pathways and large-scale impact, Deep-Sea Res. I, 51, 383-400, 2003.

De Ruijter, W. P. M., Ridderinkhof, H., and Schouten, M. W.: Variability of the southwest Indian Ocean. Phil. Trans. Roy. Soc. London, A363, 63-76, 2005.

De Ruijter, W. P. M., Brummer, G.-J. A., Drijfhout, S. S., Lutjeharms, J. R. E., Peeters, F., Ridderinkhof, H., van Aken, H., and van Leeuwen, P. J.: Observations of the inter-ocean exchange around South Africa, Eos, Trans. Am. Geophys. Un., 87, 97, 99, 101, 2006.

De Steur, L., van Leeuwen, P. J., and Drijfhout, S. S.: Tracer leakage from modeled Agulhas rings, J. Phys. Oceanogr., 34, 13871399, 2004

Dijkstra, H. A. and de Ruijter, W. P. M.: Barotropic instabilities of the Agulhas Current system and their relation to ring formation, J. Mar. Res., 59, 517-533, 2001a.

Dijkstra, H. A. and de Ruijter, W. P. M.: On the physics of the Agulhas: steady retroflection regimes, J. Phys. Oceanogr., 31, 2971-2985, 2001b.

DiMarco, S. F., Chapman, P., and Nowlin, W. D.: Satellite observations of upwelling on the continental shelf south of Madagascar, Geophys. Res. Lett., 27, 3965-3968, 2000.

Donohue, K. A., Firing, E., and Beal, L.: Comparison of three velocity sections of the Agulhas Current and Agulhas Undercurrent, J. Geophys. Res., 105, 28 585-28 593, 2000.

Duncombe Rae, C. M.: Agulhas retroflection rings in the South Atlantic Ocean; an overview, S. Afr. J. Mar. Sci., 11, 327-344, 1991.

Flemming, B. W.: Sand transport and bedform patterns on the continental shelf between Durban and Port Elizabeth (Southeast African Continental Margin), Sediment. Geol., 26, 179-205, 1980.

Flemming, B. and Hay, R.: Sediment distribution and dynamics of the Natal continental shelf, in: Coastal Ocean Studies off Natal, South Africa, edited by: Schumann, E. H., Lecture Notes on Coastal and Estuarine Studies 26, Springer-Verlag, Berlin, pp. 47-80, 1988.

Garzoli, S. L. and Goni (sic), J.: Combining altimeter observations and oceanographic data for ocean circulation and climate studies, in: Satellites, Oceanography and Society, edited by: Halpern, D., Elsevier Oceanography Series 63, Elsevier, Amsterdam, pp. 7997, 2000.

Gill, A. E. and Schumann, E. H.: Topographically induced changes in the structure of an inertial coastal jet: application to the Agulhas Current, J. Phys. Oceanogr., 9, 975-991, 1979.

Gordon, A. L., Horai, K.-I., and Donn, M.: Southern hemisphere western boundary current variability revealed by GEOS 3 altimeter, J. Geophys. Res., 88, 755-762, 1983.

Gordon, A. L.: Indian-Atlantic transfer of thermocline water at the Agulhas retroflection, Science, 227, 1030-1033, 1985.

Gordon, A. L.: Inter-ocean exchange of thermocline water, J. Geophys. Res., 91, 5037-5046, 1986.

Gordon, A. L., Lutjeharms, J. R. E., and Gründlingh, M. L.: Stratification and circulation at the Agulhas Retroflection, Deep-Sea Res., 34, 565-599, 1987.

Goschen, W. S. and Schumann, E. H.: Ocean current and temperature structures in Algoa Bay and beyond in November 1986, S. Afr. J. Mar. Sci., 7, 101-116, 1988.

Goschen, W. S. and Schumann, E. H.: An Agulhas Current intrusion into Algoa Bay during August 1988, S. Afr. J. Mar. Sci., 14, 47 57, 1994

Gründlingh, M. L.: A description of inshore current reversals off Richards Bay based on airborne radiation thermometry, DeepSea Res., 21, 47-55, 1974.

Gründlingh, M. L.: Drift of a satellite-tracked buoy in the southern Agulhas Current and Agulhas Return Current, Deep-Sea Res. 25, 1209-1224, 1978.

Gründlingh, M. L.: Observation of a large meander in the Agulhas Current, J. Geophys. Res., 84, 3776-3778, 1979.

Gründlingh, M. L.: On the volume transport of the Agulhas Current, Deep-Sea Res., 27, 557-563, 1980.

Gründlingh, M. L.: On the course of the Agulhas Current, S. Afr. Geogr. J., 65, 49-57, 1983.

Gründlingh, M. L.: Altimetry in the southwest Indian Ocean, S. Afr. J. Sci., 84, 568-573, 1988 .

Gründlingh, M. L., Stavropoulos, C. C., and Watt, L. J.: The R. V. Meiring Naudé: Two decades of support to physical oceanography, S. Afr. J. Sci., 84, 746-748, 1988.

Gründlingh, M. L. and Pearce, A. F.: Frontal features of the Agulhas Current in the Natal Bight, S. Afr. Geogr. J., 72, 11-14, 1990.

Gründlingh, M. L.: Agulhas Current meanders: review and a case study, S. Afr. Geogr. J., 74, 19-28, 1992.

Harris, T. F. W.: Planetary-type waves in the South West Indian Ocean, Nature, 227, 1043-1044, 1970.

Harris, T. F. W.: Sources of the Agulhas Current in the spring of 1964, Deep-Sea Res., 19, 633-650, 1972.

Harris, T. F. W., Legeckis, R., and van Forest (sic), D.: Satellite infra-red images in the Agulhas Current system, Deep-Sea Res., 25, 543-548, 1978.

Jacobs, S. S. and Georgi, D. T.: Observations on the Southwest Indian/Antarctic Ocean, Deep-Sea Res., 24 (supplement), 43-84, 1977.

Kamenkovich, V. M., Leonov, Y. P., Nechaev, D. A., Byrne, D. A., and Gordon, A. L.: On the influence of bottom topography on the Agulhas eddy, J. Phys. Oceanogr., 26, 892-192, 1996.

Katsman, C. A., van der Vaart, P. C. F., Dijkstra, H. A., and de Ruijter, W. P. M.: Stability of multilayer ocean vortices: a parameter study including realistic Gulf Stream and Agulhas Rings, J. Phys. Oceanogr., 33, 1197-1218, 2003.

Kostianoy, A. G., Ginzburg, A. I., Frankignoulle, M., and Delille, B.: Fronts in the southern Indian Ocean as inferred from satellite sea surface temperature data, J. Mar. Syst., 45, 55-73, 2004. 
Lee-Thorp, A. M., Rouault, M., and Lutjeharms, J. R. E.: Cumulus cloud formation above the Agulhas Current, S. Afr. J. Sci., 94, 351-354, 1998.

Lee-Thorp, A. M., Rouault, M., and Lutjeharms, J. R. E.: Moisture uptake in the boundary layer above the Agulhas Current: a case study, J. Geophys. Res., 104, 1423-1430, 1999.

Llido, J., Garçon, V. Lutjeharms, J. R. E., and Sudre, J.: Event-scale blooms drive enhanced primary productivity at the Subtropical Convergence, Geophys. Res. Lett., 32, L5611, doi:10.1029/2005GL022880, 2005.

Luther, M. E. and O'Brien, J. J.: Modelling the variability in the Somali Current, in: mesoscale/Synoptic Coherent Structures in Geophysical Turbulence, edited by: Nihoul, J. C. J. and Jamart, B. M., Elsevier, Amsterdam, pp. 373-386, 1989.

Lutjeharms, J. R. E.: Retroflection; When the current turns, Oceans, 13, 31, 1980.

Lutjeharms, J. R. E.: Features of the southern Agulhas Current circulation from satellite remote sensing, S. Afr. J. Sci., 77, 231236, 1981.

Lutjeharms, J. R. E., Bang, N. D., and Duncan, C. P.: Characteristics of the currents east and south of Madagascar, Deep-Sea Res., 28, 879-899, 1981.

Lutjeharms, J. R. E. and Valentine, H. R.: Southern Ocean thermal fronts south of Africa, Deep-Sea Res., 31, 1461-1476, 1984.

Lutjeharms, J. R. E. and van Ballegooyen, R. C.: Topographic control in the Agulhas Current system, Deep-Sea Res., 31, 13211337, 1984.

Lutjeharms, J. R. E., Mey, R. D., and Hunter, I. T.: Cloud lines over the Agulhas Current, S. Afr. J. Sci., 82, 635-640, 1986 a.

Lutjeharms, J. R. E., Allanson, B. R., and Parker, L.: Frontal zones, chlorophyll and primary production patterns in the surface waters of the Southern Ocean south of Africa, in: Marine Interfaces Ecohydrodynamics, edited by: Nihoul, J. C. J., Elsevier, Amsterdam, pp. 105-117, 1986b.

Lutjeharms, J. R. E.: Die Subtropiese Konvergensie en Agulhasretrofleksievaart (SCARC), S. Afr. J. Sci., 83, 454-456, 1987.

Lutjeharms, J. R. E. and Gordon, A. L.: Shedding of an Agulhas Ring observed at sea, Nature, 325, 138-140, 1987.

Lutjeharms, J. R. E. and Meeuwis, J. M.: The extent and variability of the South East Atlantic upwelling, S. Afr. J. Mar. Sci., 5, 5162, 1987.

Lutjeharms, J. R. E. and Stockton, P. L.: Kinematics of the upwelling front off Southern Africa, S. Afr. J. Mar. Sci., 5, 35-49, 1987.

Lutjeharms, J. R. E.: Examples of extreme circulation events of the Agulhas Retroflection, S. Afr. J. Sci., 84, 584-586, 1988a.

Lutjeharms, J. R. E.: Meridional heat transport across the SubTropical Convergence by a warm eddy, Nature, 331, 251-253, 1988b.

Lutjeharms, J. R. E.: On the role of the East Madagascar Current as a source of the Agulhas Current, S. Afr. J. Sci., 84, 236-238, 1988c.

Lutjeharms, J. R. E.: Remote sensing corroboration of retroflection of the East Madagascar Current, Deep-Sea Res., 35, 2045-2050, 1988d.

Lutjeharms, J. R. E. and Jorge da Silva, A.: The Delagoa Bight eddy, Deep-Sea Res., 35, 619-634, 1988.

Lutjeharms, J. R. E. and Roberts, H. R.: The Natal pulse; an extreme transient on the Agulhas Current, J. Geophys. Res., 93, 631-645,
1988.

Lutjeharms, J. R. E. and Valentine, H. R.: Eddies at the SubTropical Convergence south of Africa, J. Phys. Oceanogr., 18, 761-774, 1988a.

Lutjeharms, J. R. E. and Valentine, H. R.: On mesoscale ocean eddies at the Agulhas Plateau, S. Afr. J. Sci., 84, 194-200, 1988 b.

Lutjeharms, J. R. E. and van Ballegooyen, R. C.: Anomalous upstream retroflection in the Agulhas Current, Science, 240, 17701772, 1988a.

Lutjeharms, J. R. E. and van Ballegooyen, R. C.: The retroflection of the Agulhas Current, J. Phys. Oceanogr., 18, 1570-1583, 1988 b.

Lutjeharms, J. R. E. and Connell, A. D.: The Natal Pulse and inshore counter currents off the South African east coast, S. Afr. J. Sci., 85, 533-535, 1989.

Lutjeharms, J. R. E., Gründlingh, M. L., and Carter, R. A.: Topographically induced upwelling in the Natal Bight, S. Afr. J. Sci., 85, 310-316, 1989a.

Lutjeharms, J. R. E., Catzel, R., and Valentine, H. R.: Eddies and other border phenomena of the Agulhas Current, Cont. Shelf Res., 9, 597-616, 1989b.

Lutjeharms, J. R. E., Shillington, F. A., and Duncombe Rae, C. M.: Observations of extreme upwelling filaments in the South East Atlantic Ocean, Science, 253, 774-776, 1991.

Lutjeharms, J. R. E., de Ruijter, W. P. M., and Peterson, R. G.: Interbasin exchange and the Agulhas retroflection; the development of some oceanographic concepts, Deep-Sea Res., 39, 1791-1807, 1992.

Lutjeharms, J. R. E. and Thomson, J. A.: Commercializing the CSIR and the death of science, S. Afr. J. Sci., 89, 8-14, 1993.

Lutjeharms, J. R. E. and Cooper, J.: Interbasin leakage through Agulhas Current filaments, Deep-Sea Res. I, 43, 213-238, 1996.

Lutjeharms, J. R. E., Meyer, A. A., Ansorge, I. J., Eagle, G. A., and Orren, M. J.: The nutrient characteristics of the Agulhas Bank, S. Afr. J. Mar. Sci., 17, 253-274, 1996.

Lutjeharms, J. R. E.: Coastal hydrography, in: A Field Guide to the Eastern and Southern Cape Coast, edited by: Lubke, R. and de Moor, I., The Wildlife and Environment Society of Southern Africa, Grahamstown, University of Cape Town Press, Rondebosch, pp. 50-61, 1998.

Lutjeharms, J. R. E. and Machu, E.: An upwelling cell inshore of the East Madagascar Current, Deep-Sea Res. I, 47, 2405-2411, 2000.

Lutjeharms, J. R. E., Valentine, H. R., and van Ballegooyen, R. C.: The hydrography and water masses of the Natal Bight, South Africa, Cont. Shelf Res., 20, 1907-1939, 2000a.

Lutjeharms, J. R. E., Cooper, J., and Roberts, M.: Upwelling at the inshore edge of the Agulhas Current, Cont. Shelf Res., 20, 737-761, 2000b.

Lutjeharms, J. R. E., de Ruijter, W. P. M., Ridderinkhof, H., van Aken, H., Veth, C., van Leeuwen, P. J., Drijfhout, S. S., Jansen, J. H. F., and Brummer, G.-J. A.: MARE and ACSEX: new research programmes on the Agulhas Current system, S. Afr. J. Sci., 96, 105-110, 2000c.

Lutjeharms, J. R. E., Wedepohl, P. M., and Meeuwis, J. M.: On the surface drift of the East Madagascar and the Mozambique Currents, S. Afr. J. Sci., 96, 141-147, 2000d.

Lutjeharms, J. R. E. and Ansorge, I.: The Agulhas Return Current, J. Mar. Syst., 30, 115-138, 2001. 
Lutjeharms, J. R. E., Boebel, O., van der Vaart, P. C. F., de Ruijter, W. P. M.,. Rossby, T. H., and Bryden, H. L.: Evidence that the Natal Pulse controls the Agulhas Current over its full depth, Geophys. Res. Lett., 28, 3449-3452, 2001.

Lutjeharms, J. R. E. and Fillis, C. S.: Intrusion of sub-Antarctic water across the Subtropical Convergence south of Africa, S. Afr. J. Sci., 99, 173-176, 2003.

Lutjeharms, J. R. E. and Kortum, G.: On the influence of German marine research on South African physical oceanography since 1890, Historisch-meereskundliches Jahrbuch, 9, 81-100, 2003.

Lutjeharms, J. R. E., Penven, P., and Roy, C.: Modelling the shearedge eddies of the southern Agulhas Current, Cont. Shelf Res., 23, 1099-1115, 2003a.

Lutjeharms, J. R. E., Boebel, O., and Rossby, T.: Agulhas cyclones, Deep-Sea Res. II, 50, 13-34, 2003b.

Lutjeharms, J. R. E.: The coastal oceans of south-eastern Africa, in: The Sea, volume 14B, edited by: Robinson, A. R., Brink, K. H., pp. 783-834, 2006a.

Lutjeharms, J. R. E.: The Agulhas Current, Springer-Verlag, Berlin, 329 pp., $2006 b$.

Lutjeharms, J. R. E. and Kortum, G.: German research on the Agulhas Current system between the World Wars; a lost scientific achievement, Historisch-meereskundliches Jahrbuch, 11, 73-98, 2006.

Machu, E., Lutjeharms, J. R. E., Webb, A. M., and van Aken, H. M.: First hydrographic evidence of the southeast Madagascar upwelling cell, Geophys. Res. Lett., 29, 2009, doi:10.1029/2002GL015381, 2003.

Malan, O. G. and Schumann, E. H.: Natal shelf circulation revealed by Landsat imagery, S. Afr. J. Sci., 75, 136-137, 1979.

Matano, R. P.: A numerical study of the Agulhas retroflection: the role of bottom topography, J. Phys. Oceanogr., 26, 2267-2279, 1996.

Meyer, A. A., Lutjeharms, J. R. E., and de Villiers, S.: The nutrient characteristics of the Natal Bight, South Africa, J. Mar. Syst., 35, 11-37, 2002.

Michaelis, G.: Die Wasserbewegung an der Oberfläche des Indischen Ozeans im Januar und Juli, Veröffentlichungen des Instituts für Meereskunde an der Universität Berlin, n.f. A8(16): 32 pp., 1923.

Morrow, R., Birol, F., Griffen, D., and Sudre, J.: Divergent pathways of cyclonic and anti-cyclonic eddies, Geophys. Res. Lett., 31, L24311, doi:10.1029/2004GLO20974, 2004.

Nehring, D., Hagen, E., Jorge da Silva, A., Schemainda, R., Wolf, G., Michelsen, N., Kaiser, W., Postel, L., Gosselck, F., Brenning, U., Kuhner, E., Arlt, G., Siegel, H., Gohs, L., and Bublitz, G.: Results of oceanological studies in the Mozambique Channel in February-March 1980, Beit. Meeresk., 56, 51-63, 1987.

Olson, D. B. and Evans, R. H.: Rings of the Agulhas Current, DeepSea Res., 33, 27-42, 1986.

Olson, D. B., Fine, R. A., and Gordon, A. L.: Convective modifications of water masses in the Agulhas, Deep-Sea Res., 39 (Supplement 1): s163-s181, 1992.

Paech, H.: Die Oberflächenströmungen um Madagascar in ihrem Jährlichen Gang, Veröffentlichungen des Instituts für Meereskunde an der Universität Berlin, n.f. A(16): 39 pp., 1926.

Pazan, S. and Niiler, P.: New global drifter data set available, Eos, Trans. Am. Geophys. Un., 86, 17, 2004.

Pearce, A. F.: Some features of the upper $500 \mathrm{~m}$ of the Agulhas
Current, J. mar. Res., 35, 731-753, 1977.

Pearce, A. F., Schumann, E. H., and Lundie, G. S. H.: Features of the shelf circulation off the Natal coast, S. Afr. J. Sci., 74, 328331, 1978.

Peeters, F. J. C., Acheson, R., Brummer, G.-J. A., de Ruijter, W. P. M., Ganssen, G. M., Schneider, R. R., Ufkes, E., and Kroon, D.: Vigorous exchange between Indian and Atlantic Ocean at the end of the last five glacial periods, Nature, 430, 661-665, 2004.

Penven, P., Lutjeharms, J. R. E., Marchesiello, P., Weeks, S. J., and Roy, C.: Generation of cyclonic eddies by the Agulhas Current in the lee of the Agulhas Bank, Geophys. Res. Lett., 28, 10551058, 2001.

Penven, P., Lutjeharms, J. R. E., and Florenchie, P.: Madagascar: a pacemaker for the Agulhas Current system? Geophys. Res. Lett. 33, L17609, doi:10.1029/2006GL 026854, 2006.

Pillsbury, R. D., Bottero, J. M., Pittock, G., Root, D. C., Simpkins, J., and Still, R. E.: Benguela Source and Transport Project (BEST): Current measurements off the coast of South Africa. WOCE ACM-4, June 1992-October 1993, OSU Data Report 157, Reference 94-3, Corvallis, 69 pp., 1994.

Quartly, G. D. and Srokosz, M. A.: SST observations of the Agulhas and East Madagascar retroflections by the TRMM Microwave imager, J. Phys. Oceanogr., 32, 1585-1592, 2002.

Quartly, G. D. and Srokosz, M. A.: Eddies in the southern Mozambique Channel, Deep-Sea Res. II, 51, 69-83, 2004.

Rau, A. J., Rogers, J., Lutjeharms, J. R. E., Giraureau, J., LeeThorp, J. A., Chen, M.-T., and Waelbroeck, C.: A 450-kyr record of hydrographical conditions on the western Agulhas Bank slope, south of Africa, Mar. Geology, 180, 183-201, 2002.

Reason, C. J. C.: Evidence for the influence of the Agulhas Current on regional atmospheric circulation patterns, J. Climate, 14, 2769-2778, 2001.

Rennell, J.: An investigation of the currents of the Atlantic Ocean, and of those which prevail between the Indian Ocean and the Atlantic, J. G. and F. Rivington, London, edited by: Purdy, J., viii +359 pp. +2 folding maps, 1832 .

Richardson, P. L. and Garzoli, S. L.: Characteristics of intermediate water flows in the Benguela Current as measured with RAFOS floats, Deep-Sea Res. II, 50, 87-118, 2003.

Ridderinkhof, H. and de Ruijter, W. P. M.: Moored current observations in the Mozambique Channel, Deep-Sea Res. II, 50, 1933 1955, 2003.

Rouault, M. and Lutjeharms, J. R. E.: Air-sea interaction in the marine atmosphere boundary layer: a new South African research venture, S. Afr. J. Sci., 90, 11-12, 1994.

Rouault, M., Lee-Thorp, A., Ansorge, I., and Lutjeharms, J.: Agulhas Current Air-Sea Interaction Experiment, S. Afr. J. Sci., 91, 493-496, 1995.

Rouault, M. and Lutjeharms, J. R. E.: Air-sea exchange over an Agulhas eddy at the Subtropical Convergence, Global Atmos. Ocean Syst., 7, 125-150, 2000.

Rouault, M., Lee-Thorp, A. M., and Lutjeharms, J. R. E.: The atmospheric boundary layer above the Agulhas Current during alongcurrent winds, J. Phys. Oceanogr., 30, 40-50, 2000.

Rouault, M., White, S. A., Reason, C. J. C., Lutjeharms J. R. E., and Jobard, I.: Ocean-atmosphere interaction in the Agulhas Current and a South African extreme weather event, Weather Forecast., 17, 655-669, 2002.

Rouault, M. and Lutjeharms, J. R. E.: Estimation of sea-surface 
temperature around southern Africa from satellite-derived microwave observations, S. Afr. J. Sci., 99, 489-494, 2003.

Sætre, R. and Jorge da Silva, A.: The circulation of the Mozambique Channel, Deep-Sea Res., 31, 485-508, 1984.

Schmid, C., Boebel, O., Zenk, W., Lutjeharms, J. R. E., Garzoli, S., Richardson, P. L., and Barron, C.: Early evolution of an Agulhas ring, Deep-Sea Res. II, 50, 141-166, 2003.

Schmitz, W. J.: On the eddy field in the Agulhas Retroflection, with some global considerations, J. Geophys. Res., 101, 16259$16271,1996$.

Schouten, M. W., de Ruijter, W. P. M., van Leeuwen, P. J., and Lutjeharms, J. R. E.: Translation, decay and splitting of Agulhas rings in the south-eastern Atlantic ocean, J. Geophys. Res., 105, 21913-21 925, 2000.

Schouten, M. W., de Ruijter, W. P. M., and van Leeuwen, P. J.: Upstream control of Agulhas ring shedding, J. Geophys. Res., 107, doi:10.1029/2001JC000804, 2002a.

Schouten, M. W., de Ruijter, W. P. M., van Leeuwen, P. J., and Dijkstra, H.: A teleconnection between the equatorial and southern Indian Ocean, Geophys. Res. Lett., 29, 1812, doi:10.1029/2001GL014542, 2002b.

Schouten, M. W., de Ruijter, W. P. M., van Leeuwen, P. J., and Ridderinkhof, H.: Eddies and variability in the Mozambique Channel, Deep-Sea Res. II, 50, 1987-2003, 2003.

Schumann, E. H.: Inshore circulation of the Agulhas Current off Natal, J. Mar. Res., 40, 43-55, 1982.

Schumann, E. H., Perrins, L.-A., and Hunter, I. T.: Upwelling along the south coast of the Cape Province, South Africa, S. Afr. J. Sci., 78, 238-242, 1982.

Schumann, E. H., Ross, G. J. B., and Goschen, W. S.: Cold water events in Algoa Bay and along the Cape south coast, South Africa, in March/April 1987, S. Afr. J. Sci., 84, 579-584, 1988.

Shannon, L. V.: The Cape Nimbus-7 CZCS programme: An overview and preliminary results, S. Afr. J. Sci., 75, 564, 1979.

Shannon, L. V., Lutjeharms, J. R. E., and Agenbag, J. J.: Episodic input of Subantarctic water into the Benguela region, S. Afr. J. Sci., 85, 317-332, 1989.

Shillington, F. A., Peterson, W. T., Hutchings, L., Probyn, T. A., Waldron, H. N., and Agenbag, J. J.: A cool upwelling filament off Namibia, southwest Africa: preliminary measurements of physical and biological features, Deep-Sea Res., 37, 1753-1772, 1990.

Stramma, L.: The South Indian Ocean Current, J. phys. Oceanogr., 22, 421-430, 1992.

Stramma, L. and Lutjeharms, J. R. E.: The flow field of the subtropical gyre of the South Indian Ocean, J. Geophys. Res., 102, 5513-5530, 1997.

Swallow, J. C., Fieux, M., and Schott, F.: The boundary currents east and north of Madagascar. Part I. Geostrophic currents and transports, J. geophys. Res., 93, 4951-4962, 1988.
Swart, V. P. and Largier, J. L.: Thermal structure of Agulhas Bank water, S. Afr. J. Mar. Sci., 5, 243-253, 1987.

Van Aken, H., van Veldhoven, A. K., Veth, C., de Ruijter, W. P. M., van Leeuwen, P. J., Drijfhout, S. S., Whittle, C. P., and Rouault, M.: Observations of a young Agulhas ring, Astrid, during MARE, the Mixing of Agulhas Rings Experiment, in March 2000, Deep-Sea Res. II, 50, 167-195, 2003.

Van Ballegooyen, R. C., Gründlingh, M. L., and Lutjeharms, J. R. E.: Eddy fluxes of heat and salt from the southwest Indian Ocean into the southeast Atlantic Ocean: a case study, J. Geophys. Res., 99, 14 053-14 070, 1994.

Van Gogh, J.: Uitkomsten van Wetenskap en Ervaring aangaande winden en zeestromingen in sommige gedeelten van den oseaan, Koninklijk Nederlandsch Meteorologisch Instituut, Bosch en Zoon, 74 pp., 1857.

Van Gogh, J.: De stormen nabij de Kaap de Goede Hoop in verband beschouwd met de temperatuur der zee, Verhandelingen en Mededelingen der Koninklijke Akademie, afdeling Natuurkunde, 8, 23 pp., 1858.

Van Leeuwen, P. J., de Ruijter, W. P. M., and Lutjeharms, J. R. E.: Natal Pulses and the formation of Agulhas rings, J. Geophys. Res., 105, 6425-6436, 2000.

Walker, N. D. and Mey, R. D.: Ocean/atmosphere heat fluxes within the Agulhas Retroflection region, J. Geophys. Res., 93, 15473 $15483,1988$.

Walker N. D. and Lindesay, J. A.: Preliminary observations of oceanic influences on the February-March 1988 floods in central South Africa, S. Afr. J. Sci., 85, 164-169, 1989.

Walker, N. D.: Links between South African summer rainfall and temperature variability of the Agulhas and Benguela Current Systems, J. Geophys. Res., 95, 3297-3319, 1990.

Weeks, S. J. and Shillington, F. A.: Phytoplankton pigment distribution and frontal structure in the subtropical convergence region south of Africa, Deep-Sea Res. I, 43, 739-768, 1996.

Weijer, W., de Ruijter, W. P. M., Dijkstra, H. A., and van Leeuwen, P. J.: Impact of interbasin exchange on the Atlantic overturning circulation, J. Phys. Oceanogr., 29, 2266-2284, 1999.

Weijer, W., de Ruijter, W. P. M., and Dijkstra, H. A.: Stability of the Atlantic overturning circulation: competition between Bering Strait freshwater flux and Agulhas heat and salt sources, J. Phys. Oceanogr., 31, 2385-2402, 2001.

Weijer, W., de Ruijter, W. P. M., Sterl, A., and Drijfhout, S. S.: Response of the Atlantic overturning circulation to South Atlantic sources of buoyancy, Global Planet. Change, 34, 293-311, 2002.

Wüst, G.: Proposed International Indian Ocean Expedition, 1962 1963, Deep-Sea Res., 6, 245-249, 1960.

Wyrtki, K.: Oceanographic Atlas of the International Indian Ocean Expedition, National Science Foundation, Washington, D.C., 531 pp., 1971. 